\title{
A Study on Technology Competition of Graphene Biomedical Technology Based on Patent Analysis
}

\author{
Xi Yang ${ }^{1,2} \mathbb{C}$, Xin Liu ${ }^{2,3, *}$ and Jun Song 4 (1) \\ 1 School of Management, Huazhong University of Science and Technology, Wuhan 430074, China \\ 2 Center of Knowledge Innovation and Intellectual Property Research, Southwest Jiaotong University, \\ Chengdu 610031, China \\ 3 School of Public Affairs and Law, Southwest Jiaotong University, Chengdu 610031, China \\ 4 School of Materials, University of Manchester, Manchester M13 9PL, UK \\ * Correspondence: liuxin@swjtu.edu.cn; Tel.: +86-159-8212-7007
}

Received: 23 April 2019; Accepted: 25 June 2019; Published: 28 June 2019

\begin{abstract}
Graphene, with high biocompatibility, physiological solubility and stability, has been reported as an emerging material for biomedical applications such as biosensors, drug delivery, and tissue engineering. Recently, identifying the technological competition (TC) of graphene biomedical technology has received worldwide attention from stakeholders. However, few studies have attached great importance to review the TC of this field by the analysis of patents. The main objective of this study is to develop a new and comprehensive method to investigate TC in a given technology field by conducting a patent review and then employing a patent roadmap to dig out the technology opportunity. The effectiveness of the approach is verified with the case study on graphene biomedical technology. Compared to previous research, this study makes the following important contributions. First, this study provides a new and systematic framework for the dynamic analysis of TC in a given technology field. It also extends the research perspectives of TC for industry, assignees, and technology, employs a patent roadmap to dig out technology opportunities, and enables stakeholders to understand TC from a dynamic perspective. Second, this study integrates patent analysis with a patent roadmap that has not appeared in existing methodologies of patent review. Third, it first introduces indicators (e.g., high value patent and competition position of top assignees) to the previous patent roadmap and provides a new methodology for patent roadmaps from a country level and assignee level. Finally, this study provides useful information for stakeholders interested in graphene biomedical technology, helps them to find new technology opportunities in this field, encourages them to determine the direction of future research, and has important significance for its application to diverse other emerging technologies.
\end{abstract}

Keywords: technology competition; graphene; biomedical; patent analysis; patent roadmap; technology opportunity

\section{Introduction}

The advent of the knowledge economy era has created substantial interest in the research of technology competition (TC). The successful of TC is regarded as the reaction capability to technological change [1]. Some studies have focused on firms' strategic planning in TC when technological change occurs $[2,3]$. Others have identified that organizational and technological diversity play an important role in increasing of TC, and this in turn stimulates technological innovation in the target technological field [4,5]. In the last decade, many researchers have studied the key indicators in assessing TC. Schiavone presented a six-item assessment of TC, including three variables under the perspective of company's history (old core capabilities, old technology revitalization, competitive position in the 
old market) and the other three link to its emerging context (dynamic capabilities, easiness of new market entry, extent of new technology disruption) [1]. Papachristos indicated that TC is regarded as an evolutionary process, and there are five essential factors which influence TC, namely technology learning, technological performance, supply and demand increasing returns to scale, commitment, and the rate of technology change [6].

In recent years, patent information has been widely applied at both technology assessment and forecasting, promoting the technological innovation process as well as technology policy $[7,8]$. Patent information contains a valuable resource of technical items that are useful for researchers, practitioners, and policymakers in order to analyze TC in the target technological field [9]. As a key outlet for scientific and technological development, $80 \%$ of technical items can be found in patent information [10]. The main applications of patent information include identifying the main competitors, tracking the development trend of technology, assessing the capabilities of the technological innovation or helping organizations to formulate patent strategy and planning [11-13]. Karvonen et al. indicated that patent information is a valuable source for displaying the development trend of a given technology and assessing the status quo of potential competitors, and the analysis of patent information is crucial to identify TC in a given technology field [14].

Unfortunately, although patent information is significant in identifying TC, few studies about the most recent patent documents of graphene biomedical technology were found within the reviewed literature in our study. A more recent study, developed by Yang et al. [15], was given a general review of the whole graphene patenting activities, and focused on the investigation of sustainable competitive advantage (SCA) in this technical area. Considering the rapidly growth of the number of patents in graphene biomedical technology and the increasing attention on industrial applications in this field [16], it is crucial to understand the following two questions:

1. What are the existing leading country/region, top assignees, and technological hotspots and fronts in patenting activity of graphene biomedical technology?

2. What are the development trends and potential opportunities from country level and assignee level patent roadmaps in this field?

Therefore, the aim of this study is to develop a new and comprehensive approach to deeply analyze TC in graphene biomedical technology. The main difference between the approach in this study and previous ones is that we integrate patent analysis and a patent roadmap in order to identify TC under a dynamic perspective. Because patent analysis and patent roadmaps are effective tools for patent visualization, they assist stakeholders to understand useful technical, legal or economic information from a large number of patent documents. The approach we proposed in this study helps both researchers and practitioners to complete the following practical tasks in the fierce market competition: finding the leading country/region, identifying key competitors, recognizing technological hotspots and fronts, and mining technology opportunity. Such advantages in this approach are critical for stakeholders to give constructive suggestions for practical and strategic patent planning (e.g., patent filing, patent distribution, patent licensing or transfers), provide useful guidance on corporate practice (e.g., mergers and acquisitions), and to obtain their competitive advantage in the given technology field.

The remaining components of this paper are organized as follows. In Section 2, we review the existing literature on patent analysis, patent roadmap, and patenting activities in graphene biomedical technology. In Section 3, we explain the methodology and detailed research procedure. Section 4 carries out the case study in graphene biomedical technology through patent analysis as well as a patent roadmap. Section 5 concludes the main findings, contributions and limitations of this study and states potential research directions in the near future.

\section{Literature Review}

The technology roadmap (TRM) is regarded as a robust approach that is widely applicable at the institutional and industrial levels, helping stakeholders to strategize, design and carry out the evolving trend of a specific technological field. It provides a structured framework to map the 
dynamic relationships that integrate technological resources, organizational objectives and the changing environment [17]. From a methodological perspective, most of the research on the TRM focuses on qualitative methods (e.g., expert interview, Delphi, scenario planning, etc.), which has a lack of validity and reliability in the TRM's construction and implementation $[18,19]$. Patent information, an objective data source, can provide useful technical items on the evolution trends of technological trajectory, as well as the status quo of TC. Patent analysis is also an objective approach to identify TC, strategize and plan the future patent layout in a specific technological field by analyzing patent information [14]. Many patent analysis tools (e.g., cluster analysis, keyword analysis, citation analysis, etc.) have been developed to identify TC in emerging technologies, such as carbon capture and storage technology, solar photovoltaic technology, care robotics, and so on [20-23]. With the rapid development of text and data processing, some visualization software, including CiteSpace, Gephi, and VOSviewer, are utilized for patent analysis [24-26].

Recently, patent documents as well as analysis approaches are widely used in the TRM, allowing us to identify potential technology opportunities in current and future markets $[19,27,28]$. With the combination of patent information and the TRM, the patent roadmap is considered as a new concept of roadmap and being made up of patent layer as well as technology layer [29]. The patent roadmap is developed with the purpose of strategizing patents to meet the requirements of technology planned on the TRM. It can also be defined as an effective tool that describes the current development of technology, forecasts the potential patents that will be filed, and plans the direction of prospective patents $[29,30]$. Compared with the TRM, less research has been performed on patent roadmaps. A previous study related to the notion of patent roadmaps was conducted by the Institute for Information Technology Advancement in Korea. This study attempts to explore the development trajectory of the global system for mobile communication and proposes a useful counterplan for patent infringement. Jeong and Yoon suggested the concept and pattern of a patent roadmap based on the TRM and evolution trends of patent. Based on a case study of transparent display-related technology, this patent roadmap aimed to obtain a core patent, develop it to a business model and then encourage stakeholders to formulate patent strategic planning [29]. Jeong et al. proposed a new patent roadmap which aims to achieve patent forecasting and planning. This approach was helpful for exploring the potential patent vacuums in the development of emerging technologies and to foresee the content of a promising research area [31]. Yu and Zhang proposed a new kind of patent roadmap, which indicates technology revolution in the target technological industry. Compared to previous research, the leading assignees, as well as their patent distribution, can be highlighted in this patent roadmap [32]. It is essential for this paper to demonstrate that a patent roadmap has distinct advantages compared to the existing TRM approach, which reveals that TC is much more credible and reliable.

Graphene, a two-dimensional nano material, was discovered by Andre Geim and Kostya Novoselov in the year 2004. Due to its unique and distinctive properties, such as high conductivity, flexibility, biocompatibility, physiological solubility and stability, graphene will be the most promising emerging material for use in biomedical applications. Kostarelos and Novoselov indicated that material characteristics, interactions with biological components (tissues, cells, and proteins), and biological activity outcomes need to be considered carefully in the development of graphene biomedical technology [33]. Recently, researchers have paid close attention to the biomedical applications of graphene, including biosensor, antibacterial, antiviral and anticancer material, therapeutics, and tissue engineering [34]. For example, recent progress in the biomedical applications of graphene have been used in sustainable biomedical devices such as blood glucose sensors and deep brain stimulators [35].

A couple of years ago, several researchers aim to review the research development and practical application of graphene biomedical technology [36,37]. As a conductive transparent nanomaterial with low cost and substantial green environmental impact, graphene is suitable for catalysis, sensing, drug delivery, electrical and bioelectronics, tissue engineering, cancer theranostics, and clinical tools $[38,39]$. Viseu et al. provided a systematic review and critical analysis emphasizing the role of graphene-based nanomaterials (GBNs) in cancer theranostics. This study also illustrated the challenges 
yet to overcome for a translation of GBNs to a clinical context of pharmaceutical applications [40]. Reina et al. proposed a tutorial review and analyzed graphene-based devices with in vitro and in vivo applications. In addition, this study addressed the toxicological impact and the limitations in translating graphene materials into advanced clinical tools [41]. Chung et al. highlighted recent efforts to apply graphene and graphene oxides (GO) to biomedical research and a few different approaches to prepare graphene materials designed for biomedical applications [42]. Graphene and GO are considered as promising materials for biomedical applications such as mass spectrometry, Field Effect Transistor (FET)/Fluorescence Resonance Energy Transfer (FRET) sensors, gene and drug delivery, stem cell differentiation, cancer treatment, and cell growth control [42]. Ghosal and Sarkar discussed the biomedical applications of graphene family nanomaterials (e.g., graphene oxide (GO), reduced graphene oxide (rGO), and graphene quantum dots (GQDs)), as well as their synthesis procedure, biocompatibility, and biomedical applications, including biosensors, bioimaging, tissue engineering, drug delivery, gene therapy, photodynamic and photothermal therapy, and their prospective future [43]. Menaa et al. reported and discussed the recent findings using graphene and derivatives as potent nanomaterials for promoting stem cell research (i.e., culture, maintenance and differentiation) and tissue engineering, as well as for regenerative, translational and personalized medicine (e.g., bone reconstruction, neural regeneration) [44]. This paper also highlighted the importance of functionalizing graphene-based nanomaterials to minimize the cytotoxic effects, as well as other critical safety parameters [44].

However, the existing research has put limited effort to investigate patenting activities of graphene. Most of the recent studies have employed patent analysis to illustrate the status quo of patent application activities [45], monitor core technological components [46], investigate the technological innovation trajectory [47], and identify the development trends of technology evolution [48] in the graphene field. Moreover, the number of existing patent reviews in this field is very few, and the patent research on graphene biomedical technology is still in the blank stage. In particular, most of the existing literature mainly focuses on counting the number of patents in this field. Dhand et al. provide a review of patenting activity and development trend in the field of graphene-based nanocomposites [49]. This research employed an annual number of patents as well as the number of patents in each subject in order to illustrate the research status and trends of graphene nanocomposites [49]. Although a report by the UK intellectual property office offers a patent landscape map for graphene and enables stakeholders to observe the development trends of worldwide patent filing in this field, it mainly focuses on general patenting trends, such as country or sector distributions, applicant collaboration, etc. [50]. In addition, a more recent study, developed by Yang et al. [15], offers a review of graphene patenting activities which aimed to assist both researchers and practitioners to obtain a sustainable competitive advantage (SCA). Since graphene biomedical technology has faced growing attention in recent years, it is of great importance to identify TC in this field by employing patent reviews and encourage stakeholders to make the correct decisions in patent strategic planning. Therefore, patent analysis and patent roadmaps are considered valuable tools for conducting a systematic and comprehensive patent review in the field of graphene biomedical technology.

\section{Methodology}

\subsection{Research Methodology}

Numerous studies have indicated that patent information has been regarded as an objective data source for providing a basis for TC $[9,14]$. The quality of patents is the most important patent indicator to measure TC in the given technology field. It is interesting to find that the top $10 \%$ of the most valuable patents were captured from $48 \%$ to $93 \%$ of the total sample value of all patents through statistical analysis [51]. In the existing studies on TC, a single research methodology is often used, and there is a focus on static research or comparison research [20,21]. Other research focuses on only assessing the number of patents $[32,52]$ where the quality of a patent is considered deficient. 
However, few have extended the research on the dynamic development trend of TC by employing a set of approaches, for example, a patent roadmap, and even fewer have emphasized the quality of patents rather than the number of patents from the perspective of a patent roadmap.

In this paper, by integrating patent analysis and a patent roadmap, we attempt to introduce new patent indicators emphasizing patent quality to the previous patent roadmap, and to build a new and systematic research framework for identifying TC in the given technology field. The methodology contribution of this paper mainly has the following aspects. First, this study first integrates patent analysis with a patent roadmap in a research review, which illustrates the dynamic development trend of TC. In existing studies on TC, few studies have combined patent analysis with a patent roadmap to show the dynamic development trend of TC. To solve the existing problems of the above research, we attempt to build patent roadmaps that are based on the systematic research perspectives (e.g., industry, assignee, and technology perspective) of patent analysis, and to illustrate the dynamic development trend of TC in the target technological filed. Second, this study introduces indicators (e.g., high value patent of leading country and competition position of top assignees) to the previous patent roadmap and provides a new methodology for patent roadmaps from country and assignee levels. The existing research on patent roadmaps is more dependent on technical experts' advice and the lack of objective data, such as patent data. Few have extended research on measuring the number of patents, but the quality of patents and geographical distribution of those patents are considered deficient. In this study, we build new patent roadmaps from both a country level and assignee level, which focus on the quality of a patent rather than those studies that only assessed the number of patents. In addition, we consider the geographical distribution of those high quality patents, and use different colors to distinguish different countries.

Collecting accurate data for patent analysis and patent roadmaps plays a crucial role in exploring TC. After reading the existing literature as well as consulting technical experts' advice, we carry out an appropriate patent retrieval query and obtain patent information from the INNOGRAPHY platform, as well as the Derwent Innovation Index (DII) platform, which are professional intellectual property databases. In Figure 1, data analysis is shown to constitute two steps. First, regarding patent analysis, this study attempts to identify TC from the perspectives of industry, assignee, and technology. Taking into account data accessibility, we attempt to use the following patent indicators to conduct patent analysis, and identify TC in graphene biomedical technology: the annual trend of patent activities, competition position of top assignees, and patent hotspots and fronts. The analysis of annual distributions or dynamic changes of the number of patents appeared to be very useful for assisting stakeholders realize development trends and TC of specific industrial domain [53]. Based on patent analysis, analyzing the assignees would identify the key actors and competitors of the technological innovation in a given technological field. To be more specific, the competitive position is of fundamental importance to help assignees obtain information about competitive status quo and competitive advantages in TC [54]. The technological hotspots and fronts can be straightforwardly identified by using text clustering analysis, which helps people identify TC from the technology dimension [32]. Second, the proposed patent roadmap aims to mine technology opportunities that can be carried out by the following steps. First, in the proposed country level patent roadmap and assignee level roadmap, the horizontal axis indicates time-line, and the vertical axis represents technological fields namely the Derwent Manual Code (MC). Second, in the country level patent roadmap, a single node shows a country holding a high value patent, while in the assignee level patent roadmap, a single node represents a top assignee. We employ different colors to represent different countries. Finally, we build the patent roadmap by using the above indicators. 


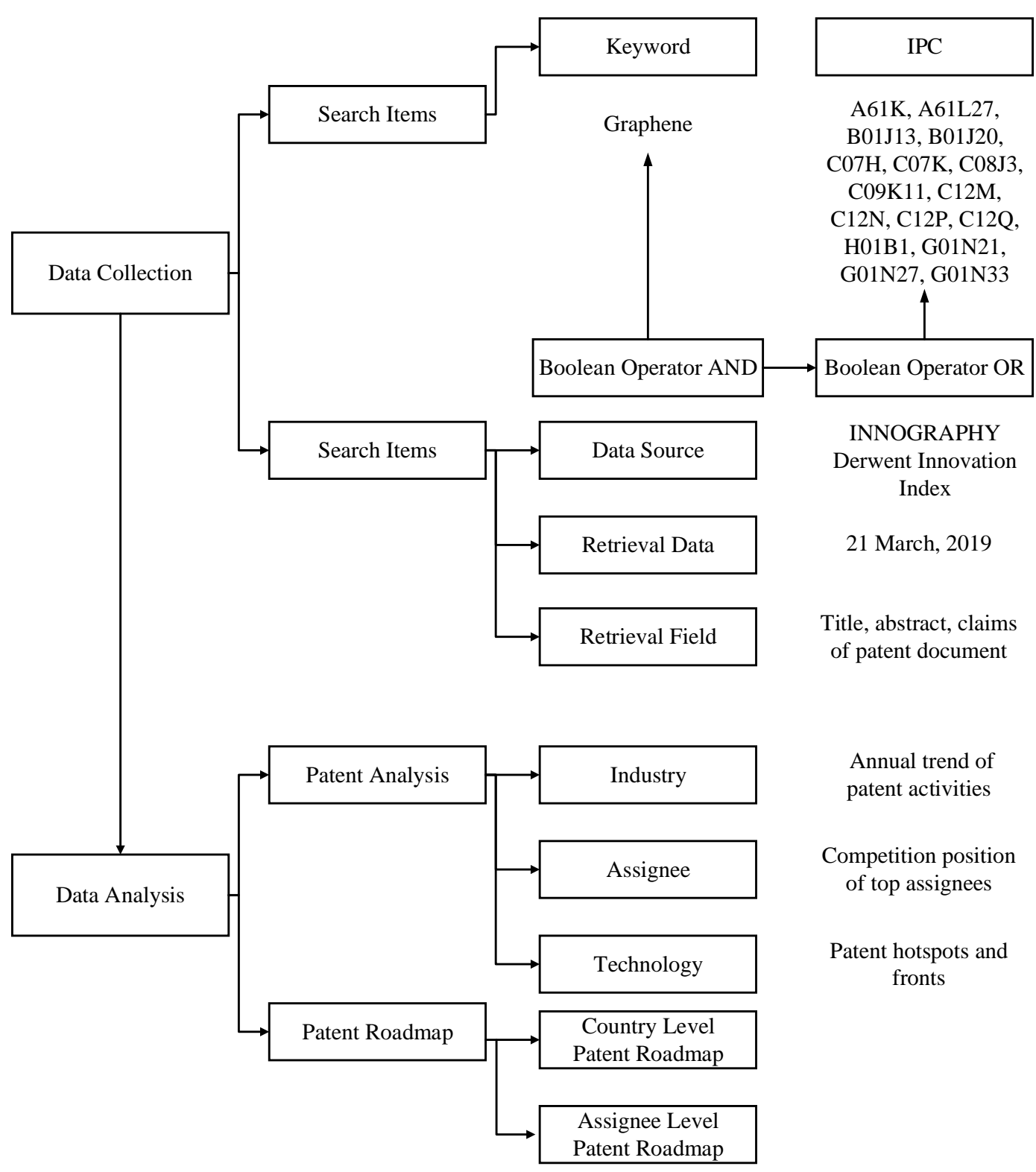

Figure 1. The outline of the research process. IPC: International Patent Classification.

\subsection{Patent Retrieval}

Investigating the TC of graphene biomedical technology through patent analysis and patent roadmap is the principle purpose of this paper. The collection process of patent data is the essential basis for patent analysis, as well as patent roadmaps. Patent data were retrieved from two professional intellectual property databases, namely INNOGRAPHY [55], and the Derwent Innovation Index (DII) [56]. In order to better improve the accuracy and relevancy of our patent data, the first effort is to construct a systematic patent retrieval query. The concept of "graphene" was based on the definition given by The International Union of Pure and Applied Chemistry (IUPAC) who regarded "graphene" as "a single carbon layer of the graphite structure" [57]. According to previous research, "graphene" can be used as a patent search string in patent queries $[15,58]$. By looking through relevant literature and consulting technical experts' advice, we employed a broader criterion for retrieving patents in a given technological field. Patent data seems to be valid if the term "graphene" appears simultaneously in the "title or abstract or claims" of patent data. In addition, we followed advice from technical experts in graphene biomedical technology, and adopted technological fields represented by the international patent classification (IPC) to refine the retrieval query and retrieve graphene patents in the 
biomedical field. Finally, our patent retrieval query for graphene biomedical technology was composed by combining the keywords with patent classifications, using the "AND" operator. For the graphene biomedical technology case, the following patent retrieval query in INNOGRAOHY is displayed below. @(abstract, claims, title)("graphene")@* and ((ipc_A61K OR ipc_A61L27 OR ipc_B01J13 OR ipc_B01J20 OR ipc_C07H OR ipc_C07K OR ipc_C08J3 OR ipc_C09K11 OR ipc_C12M OR ipc_C12N OR ipc_C12P OR ipc_C12Q OR ipc_H01B1 OR ipc_G01N21 OR ipc_G01N27 OR ipc_G01N33)). In addition, we downloaded patent data in the field of graphene biomedical technology from DII based on the same retrieval strategy and query as that in INNOGRAPHY. Due to a relatively small number of patents before 2004, we retrieved patents filed from the year of 2004 to 2018 for analysis. We completed the data extraction on March 21, 2019. However, due to the 18-month lag period of patents, the number of patents in both 2017 and 2018 are incomplete, but without impacting the analysis of TC.

\section{Analysis}

\subsection{Patent Analysis}

\subsubsection{Annual Trend of Patent Activities}

The analysis of annual distribution of patent application and development trends of the top ten countries or regions leading the graphene biomedical race are presented in this section. Figure 2 illustrates the dynamic changes of patent application for graphene biomedical technology in China, the U.S., Korea, India, the U.K, Taiwan, Japan, Germany, Canada, France and the world. We find that the number of patents for graphene biomedical technology in the global had rapidly increased since 2012. In 2010, the Nobel Prize in physics was granted to Andre Geim and Konstantin Novoselov for their amazing breakthrough on graphene [59]. After that, many countries, with substantial efforts and investments from governments, have been focused towards the research and development (R\&D) in graphene technology [60]. In addition, since the development trend of graphene has accelerated around the world, the number of graphene biomedical patents has rapidly grown. Regarding the number of patents, the top ten countries or regions hold $93.88 \%$ of global share in graphene biomedical patents. In addition, China (790 patents), the U.S. (378 patents), and Korea (271 patents) are the top three countries with more than 200 patents each. In total, the top three possess $83.08 \%$ of the global patent application in the graphene biomedical field. It is clear that China outstrips other countries or regions, and holds $45.61 \%$ of global share, suggesting its leading power in this field. One reason for this is the broad market and plentiful graphite resources in China, which offers great development opportunities for Chinese stakeholders [61]. The other reason is China's technology assessment system that put substantial effort into patents [61]. It is interesting to find that a country/region from Asia (e.g., China, Korea, Japan, and Taiwan) own the largest amount of graphene biomedical patents in total. Although the U.K, Germany and France play key roles in patenting activities in the European region, they are still far behind assignees from Asia and the U.S.

In Figure 2, the U.S., Korea, and Japan started earlier in graphene biomedical technology, and filed their first patent in 2004. While in China, the patent application had appeared since 2005, followed by Taiwan in 2007, Germany and Canada in 2008. Before the year 2010, the U.S. (55\%), Korea (12.5\%), and Japan $(12.5 \%)$ play the dominant roles in patenting activity, suggesting that these three countries obtain first-mover advantages. After 2011, the top three countries are China, the U.S., and Korea. China, with stable growth in the number of patents, becomes a technology catcher and takes the lion's share in the global market. 


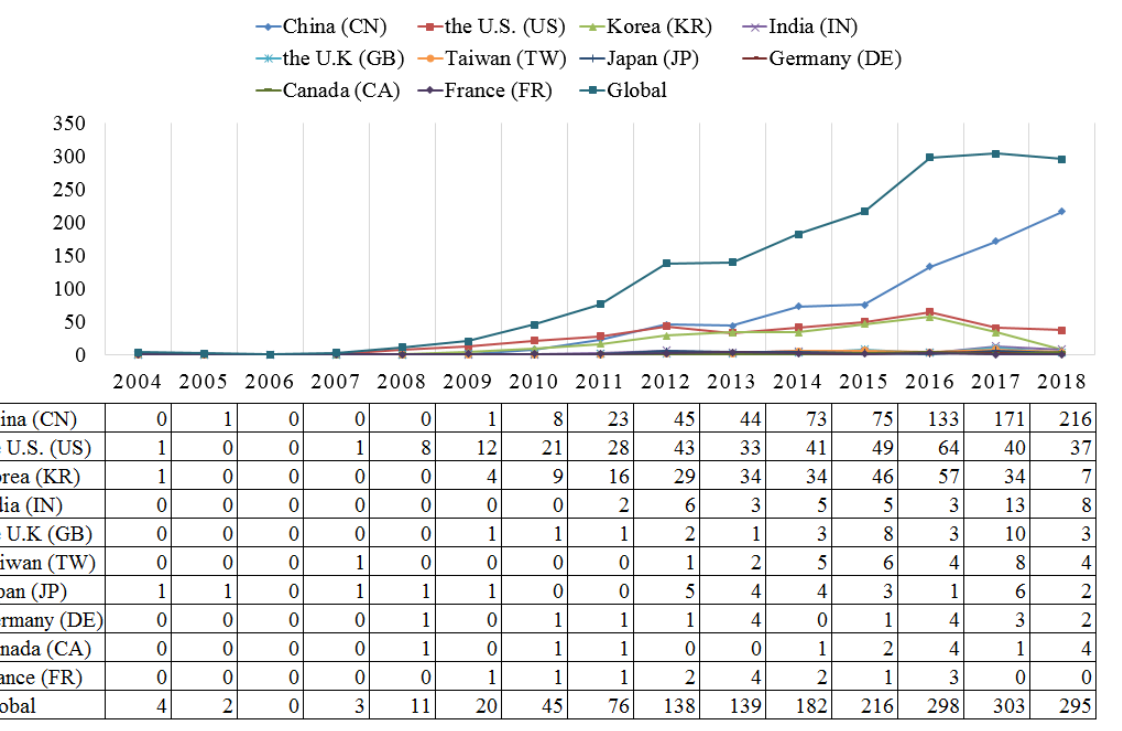

Figure 2. Annual trend of patent activities of graphene biomedical technology.

\subsubsection{Competitive Position of Top Assignees}

The INNOGRAPHY platform's patent map is a powerful visualization software that enables stakeholders to understand how a particular market or technology stacks up and explores a competitive landscape among top assignees. By also integrating multiple data dimensions (e.g., litigation, product and technology standards) into a single view, the INNOGRAPHY platforms's patent map enhances the ability to understand the TC of competitors, helping discovery of new competitors and opportunities. Three dimensions' values (e.g., revenue, litigation, and locations) related to company resources are summed and plotted on the vertical axis, while three other dimensions' values (e.g., patents, classifications, and citations) related to patent strength are summed and plotted on the horizontal axis. The higher score on the vertical axis indicates that assignees would have a greater ability to obtain resources, while the higher score on the horizontal axis indicates that assignees would also have a greater competitive strength on patenting activities. Therefore, the INNOGRAPHY platform's patent map is designed to give an overview on competitive position of top assignees in a given technology field. We employ the INNOGRAPHY platform's patent map to find the top assignees of TC in the field of graphene biomedical technology (see Figure 3).

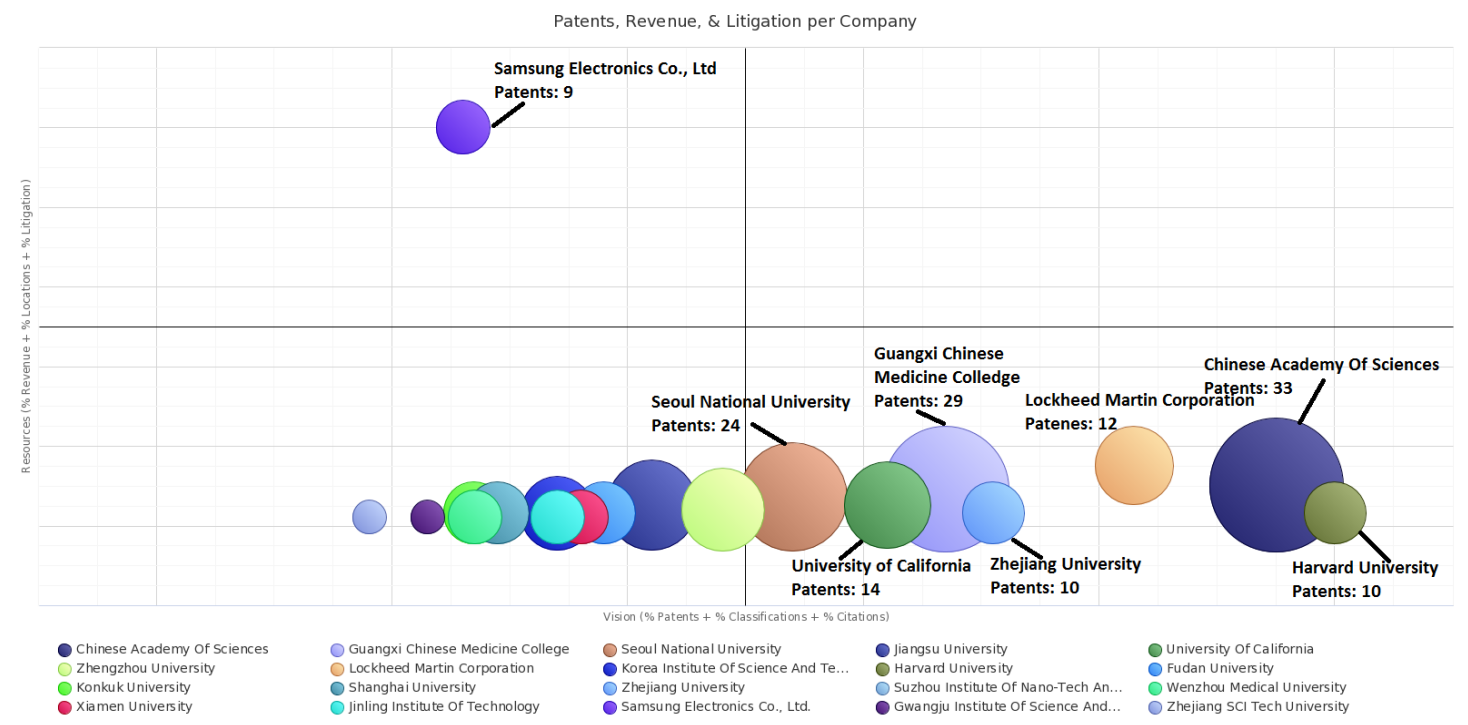

Figure 3. Competitive position of top assignees in graphene biomedical technology. 
In Figure 3, it illustrates that two assignees from enterprises and eighteen assignees from universities and research institutes. These two patentees from enterprises are Lockheed Martin Corporation from the U.S. and Samsung Electronics Co., Ltd. from Korea. It should be recognized that assignees from China are all belong to universities and research institutes, which suggest a lack of Collaboration among enterprises, universities, and research institutes. As for geographical location, China (12 assignees) overtakes Korea ( 5 assignees), and the U.S. ( 3 assignees), and takes the lion's share, indicating its principle role in graphene biomedical technology. The top three assignees regarding the number of patents are Chinese Academy of Sciences (33), Guangxi Chinese Medicine College (29), and Seoul National University (24). These assignees situated in the lower right quadrant, indicating their competitive advantages in patenting activities. Harvard University, Chinese Academy of Sciences, and Lockheed Martin Corporation have relatively higher technological innovation capability in patent strength, locating in the lower right quadrant. Lockheed Martin Corporation, holding 12 patents, is situated relatively close to the area of the upper right quadrant. This indicates that Lockheed Martin Corporation has a relatively high competitive advantage in technical strength and resources, and plays a crucial role in the future TC. It is clearly shown that there are no assignees situated in the area of the upper right quadrant, which indicate that currently no assignee is the technological and marketable leader with competitive advantage over patent activities as well as resources. Samsung Electronics Co., Ltd. is the only competitor situated in the upper left quadrant, which shows its distinct competitiveness in company resources, so it is challenger in graphene biomedical technology and will become a potential buyer. More than half of the patentees are still situated in the lower left quadrant. Most of the Chinese assignees with relatively lower technological innovation capability are situated in this quadrant. For example, although Jiangsu University, Zhengzhou University, Fudan University, and Shanghai University ranked the top 10 in owning patents, their ability in company resources is relatively low. Lacking technological strength as well as company resources, these Chinese assignees are followers.

INNOGRAPHY's PatentStrength ${ }^{\circledR}$ is a proprietary algorithm that focuses on patent value as well as relevance, and encourages stakeholders to find leading assignees holding these most valuable patents in TC. There are more than 10 indicators to calculate the patent strength, such as backward citations, forward citations, patent litigation, family numbers, claim numbers, etc. Specifically, INNOGRAPHY's PatentStrength ${ }^{\circledR}$ employs 0 to 100 scales to assess the patent strength. The larger the number of scale, the more valuable the patent. General patents cover the lower 30 scale. Patents with patent strength from 30 to 80 would be considered as important patents, while the patent strength of core patents seem to be more than 80 .

In this study, we obtain 598 important high-strength patents as of March 2019 related to graphene biomedical technology (see Table 1). Table 1 depicts the distribution of top 20 assignees holding high-strength patents. Lockheed Martin Corporation overtakes other assignees, with $83.33 \%$ of high-strength patents and a high competitive advantage in TC, followed successively by Harvard University (80.00\%), Samsung Electronics Co., Ltd. (77.78\%), University of California (57.14\%), and Suzhou Institute of Nano-Tech and Nano-Bionics CAS (55.56\%), which illustrate their relatively stronger technological innovation capability in TC. US9572918 B2 filed by Lockheed Martin Corporation is the number one patent with strongest patent strength, in which a device isolates a substance from blood. It was filed in 2013. This device may be configured to include a conduit system. It may also be configured to operate according to a reversible cycle. As for the country origin, the percentage of high-strength patents being held by the U.S.'s assignees outstrip assignees from other countries, indicating its leading position in global TC. In addition, half of Chinese assignees hold less than $10.00 \%$ high-strength patents. Guangxi Chinese Medicine College, Shanghai University, Jinling Institute of Technology, and Zhengjiang Sci-Tech University don't hold any high-strength patents, which may lead to the loss of competitive advantage in TC marketplace. 
Table 1. Top 20 assignees holding high-strength patent.

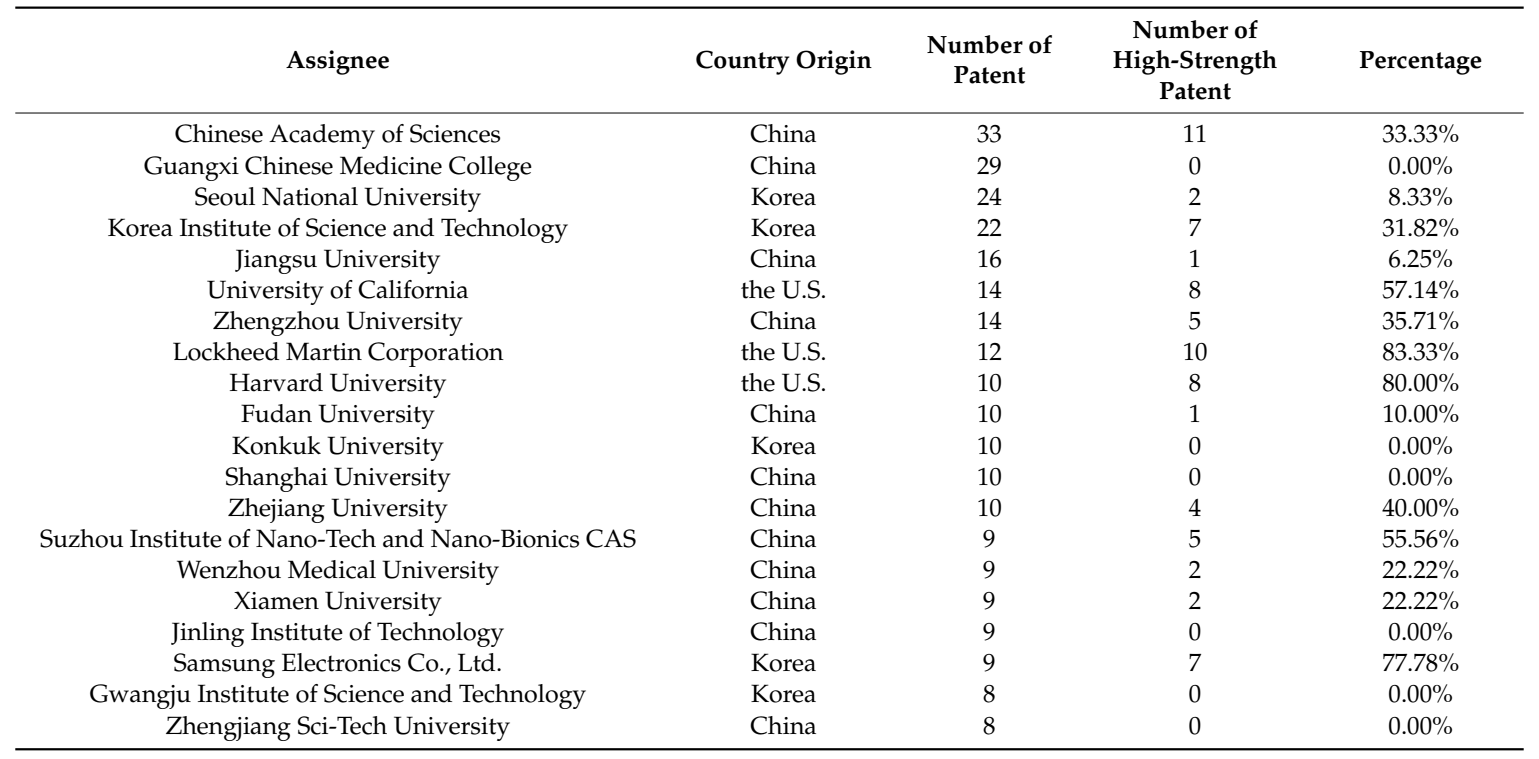

\subsubsection{Patent Hotspots and Fronts}

According to the cross-database retrieval approach, we imported the Derwent format patent data into visual analysis software CiteSpace and performed a text clustering in the field of graphene biomedical technology. By using text clustering, patent data can further dig out research hotspots and technology opportunity, which can significantly assist researchers and practitioners for strategic planning. The text clustering analysis can be completed by using the Derwent Manual Codes (MC). We adopted the MC provided by DII platform, which is a hierarchical indexing technology classification system, indicating the novel technical aspects of the invention, and its commercial applications. Currently, there are around 26,000 MC in total. The research hotspots and fronts are easily identified by employing the text clustering analysis of the MC. Citespace is a freely available and visual analysis tool that can figure out, detect, and visualize research hotspots and fronts, TC trends in the target technical area. It can improve the interpretability as well as clarity of visualization, and can be used for network analysis, co-occurrence analysis, clustering analysis, co-citation pattern analysis and so on [62,63].

In terms of text clustering analysis of the $M C$, each node shows a single $M C$, the size of the $M C$ shows the occurrence frequency of the node, and a link connecting different nodes is used to illustrating a patent has more than one MC. Regarding frequency, it is regarded as an indicator that reflects hotspots of the given technological field. The node with highest frequency likely has a greater ability to capture information and impacts on the research hotspots of graphene biomedical technology. Based on frequency, the top five MCs from high to low rank are D05-H09 (Testing and detection (Except Bacteria, Fungi, Viruses)), B12-K04 (Diagnosis and testing), B11-C12 (Nanotechnology (General)), B11-C08B (Testing/detection by potentiometry, polarography), and A12-V01 (Medicines, pharmaceuticals), which illustrates that the research hotspots' emphasize practical applications in testing as well as basic and fundamental study, for example, the excellent properties of graphene biomedical technology.

The technological field represented by the MC with high frequency represents the hotspots of the technology, while the MC with high centrality indicates the importance and influence power of specific domain of technology and represents the technology opportunity in this field. To explore the hotspots and fronts in graphene biomedical technology, we consider both frequency and centrality as indicators. Table 2 depicts the top twenty patent hotspots and fronts and their potential application in the field of graphene biomedical technology. 
Table 2. Top 20 patent hotspots and fronts of graphene biomedical technology.

\begin{tabular}{|c|c|c|c|c|c|}
\hline $\begin{array}{c}\text { 7Derwent } \\
\text { Manual Code }\end{array}$ & Technological Field & Centrality & Frequency & Biomedical Application & References \\
\hline B12-K04 & Diagnosis and testing & 0.20 & 456 & $\begin{array}{l}\text { Respiratory diseases, and cancer } \\
\text { diagnostics }\end{array}$ & [64-66] \\
\hline E05-U05C & Nanofilm & 0.15 & 188 & $\begin{array}{l}\text { Disease diagnosis, bone } \\
\text { regeneration, glucose detection, } \\
\text { artificial kidneys and dialysis }\end{array}$ & [67-69] \\
\hline L03-A02B & $\begin{array}{l}\text { Nonmetal } \\
\text { conductors_carbon and } \\
\text { graphite }\end{array}$ & 0.14 & 54 & $\begin{array}{l}\text { Interactions with biological } \\
\text { components (tissues, cells, and } \\
\text { proteins), and integrated circuits } \\
\text { in biomedical fields }\end{array}$ & {$[33,70,71]$} \\
\hline A12-V01 & $\begin{array}{c}\text { Medicines, } \\
\text { pharmaceuticals }\end{array}$ & 0.13 & 297 & $\begin{array}{l}\text { Drug delivery, tissue engineering, } \\
\text { and regenerative medicine }\end{array}$ & [72-75] \\
\hline B14-S18 & Drug combination & 0.11 & 126 & $\begin{array}{l}\text { Carrier of photosensitizers and } \\
\text { chemotherapeutics for the drug } \\
\text { combination therapy }\end{array}$ & {$[76-78]$} \\
\hline B05-B02C & $\begin{array}{c}\text { Silicon (SI), Selenium } \\
\text { (SE), Tellurium (TE), } \\
\text { Boron (B) Inorganic, } \\
\text { Inert gases }\end{array}$ & 0.10 & 100 & $\begin{array}{l}\text { An excellent adsorbent in } \\
\text { biomedical field, nucleic acid } \\
\text { detection and imaging, and } \\
\text { biosensing }\end{array}$ & [79-81] \\
\hline B05-C06 & Elemental C or S & 0.09 & 233 & $\begin{array}{c}\text { Bio-imaging (e.g., in vitro and } \\
\text { in vivo cellular imaging), bone } \\
\text { and neural tissue engineering, } \\
\text { drug delivery }\end{array}$ & [82-87] \\
\hline B05-U03 & Carbon only nanotubes & 0.09 & 96 & $\begin{array}{l}\text { The surfaces of human tissues or } \\
\text { organs, electrode arrays, and } \\
\text { sensors }\end{array}$ & [88] \\
\hline D05-H09 & $\begin{array}{l}\text { Testing and detection } \\
\text { (Except Bacteria, Fungi, } \\
\text { Viruses) }\end{array}$ & 0.08 & 487 & $\begin{array}{l}\text { Testing and detection in proteins, } \\
\text { ATP, glucose }\end{array}$ & {$[33,89-91]$} \\
\hline B04-N04 & $\begin{array}{l}\text { Protein/polypeptide of } \\
\text { undefined origin (No } \\
\text { sequence) }\end{array}$ & 0.08 & 178 & $\begin{array}{l}\text { Protein/polypeptide detection, } \\
\text { delivery of proteins }\end{array}$ & {$[92,93]$} \\
\hline B04-C03 & Polymers (General) & 0.07 & 245 & $\begin{array}{l}\text { Biosensing, neural interfacing and } \\
\text { tissue engineering }\end{array}$ & [94] \\
\hline B04-N02 & $\begin{array}{c}\text { Animal } \\
\text { protein/polypeptide (No } \\
\text { sequence) }\end{array}$ & 0.07 & 128 & $\begin{array}{l}\text { Animal protein/polypeptide } \\
\text { detection, delivery of animal } \\
\text { proteins }\end{array}$ & [95] \\
\hline $\mathrm{A} 08-\mathrm{S} 02$ & Solvents, swelling agents & 0.07 & 101 & $\begin{array}{l}\text { Fabrication of bio-composite, thin } \\
\text { films, and biosensors }\end{array}$ & {$[96,97]$} \\
\hline S03-E03C1 & Biosensors & 0.06 & 294 & $\begin{array}{l}\text { Diagnosis of diseases, pathogens, } \\
\text { and biomolecules }\end{array}$ & [98] \\
\hline A12-W11L & $\begin{array}{l}\text { (Immobilised) Enzymes } \\
\text { or microorganisms, } \\
\text { microbiology (Polymer } \\
\text { use) }\end{array}$ & 0.06 & 276 & $\begin{array}{c}\text { Glucose biosensing, enzyme } \\
\text { engineering }\end{array}$ & {$[99,100]$} \\
\hline A12-W14 & Nanotechnology & 0.06 & 259 & $\begin{array}{l}\text { Drug/gene delivery, phototherapy, } \\
\text { bioimaging, interfacial } \\
\text { biointeractions, tissue engineering }\end{array}$ & [101] \\
\hline A12-E13 & $\begin{array}{l}\text { Instrumentation; } \\
\text { measuring; } \\
\text { testing-electrical } \\
\text { engineering }\end{array}$ & 0.06 & 201 & $\begin{array}{l}\text { Biomolecule detection and DNA } \\
\text { sequencing, bio-sensors, and } \\
\text { bio-chips }\end{array}$ & [102] \\
\hline B11-C08B & $\begin{array}{l}\text { Testing/detection by } \\
\text { potentiometry, } \\
\text { polarography }\end{array}$ & 0.05 & 339 & $\begin{array}{l}\text { Biosensor in clinical diagnosis for } \\
\text { detection of proteins, nucleic acid, } \\
\text { small molecules, and pathogens }\end{array}$ & [103] \\
\hline B04-E01 & $\begin{array}{l}\text { Nucleic acid general and } \\
\text { other }\end{array}$ & 0.05 & 287 & $\begin{array}{c}\text { Targeted delivery, gene regulation, } \\
\text { intracellular detection, biosensing, } \\
\text { DNA recognition }\end{array}$ & {$[104,105]$} \\
\hline B11-C12 & $\begin{array}{l}\text { Nanotechnology } \\
\quad \text { (General) }\end{array}$ & 0.03 & 437 & $\begin{array}{c}\text { Cellular functions, pathology, } \\
\text { drug discovery, toxicology, and } \\
\text { disease diagnosis }\end{array}$ & [106] \\
\hline
\end{tabular}

In terms of high centrality and high frequency, B12-K04 (Diagnosis and testing) is the most important technological field with a centrality of 0.20 and a frequency of 456 , which outstrips other 
technological fields listed in the table. Graphene, a two-dimensional atomic crystal made up of carbon atoms, possesses superior properties to enable diagnosis and testing, especially applications in respiratory diseases, cancer diagnostics, etc. [64]. These extraordinary properties include the thinnest material, a high quantum capacitance, high carrier-phonon, and large interfacial area [65]. B12-K04 (diagnosis and testing) belongs to the section of diagnostics, respiratory active type. Currently, the methods for diagnosing and monitoring respiratory diseases are limited in characterizing the nature and degree of airway inflammation, and require costly, bulky equipment that patients cannot easily keep with them. There's an urgent need for improved, minimally invasive methods for the diagnosis and monitoring of respiratory diseases. For example, the scientists in Rutgers University-New Brunswick have created a graphene-based sensor that could lead to the earlier detection of looming asthma attacks and improve the diagnosis of asthma and other respiratory diseases, preventing hospitalizations and deaths [66]. It is followed by E05-U05C (Nanofilm), A12-V01 (Medicines, pharmaceuticals), B05-C06 (Elemental C or S), and D05-H09 (Testing and detection (Except Bacteria, Fungi, Viruses)). As for E05-U05C (Nanofilm), graphene films have superior properties, such as conductivity, sensitivity, mobility, and transparency, and have various potential biomedical applications in the fields of disease diagnosis, water desalination, and electronics. Currently, graphene film has emerged as a promising candidate for good development prospects, for instance, bone regeneration, glucose detection, artificial kidneys and dialysis, and so on. To be more specific, Lu et al. developed a self-supporting graphene hydrogel (SGH) film, which has extraordinary properties, such as good biocompatibility, osteoinductivity, appropriate mechanical strength and potential degradability. It can be well applied to direct monitoring in vivo, for instance, bone regeneration [67]. In addition, the graphene-glucose oxidase was consisted of a nano-biocomposite thin film, which used for glucose sensing and was readily applicable to the fabrication of other biosensors based on oxidases [68]. Moreover, Graphene Oxide films with more than 2-nm spacing may be produced for possible application in artificial kidneys and dialysis that require precise separation of large biomolecules and small waste molecules [69]. Due to unique properties such as super conductivity, chemical and mechanical stability, large surface area, and good biocompatibility, the impact of graphene-related materials on the technological field A12-V01 (Medicines, pharmaceuticals) are emphasized, with particular emphasis on drug delivery, tissue engineering, and regenerative medicine $[72,73]$. The latest advances in drug delivery applications include the delivery of different therapeutics such as anti-cancer drugs, DNA, genes, the concepts for targeting delivery, controlled and stimulated drug release ( $\mathrm{pH}$, temperature, photo and magnetic) and the design of graphene nanohybrids for combined therapy and imaging [74]. In addition, graphene can interact with other biomolecules such as DNA, enzymes, proteins, or peptides for tissue engineering and regenerative medicine. The outstanding mechanical strength, stiffness and electrical conductivity make graphene-based materials a good candidate for cardiac, neural, bone, cartilage, skeletal muscle, and skin/adipose tissue engineering [75]. Regarding B05-C06 (Elemental C or S), graphene can be generally considered as the mother of two-dimensional (2-D) materials. It's the only one of the conjugated carbon allotropes in which carbon is rigorously sp2 hybridized [82]. Recently, graphene and its chemical derivatives have been widely used in multifunctional biomedical applications, including bio-imaging, tissue engineering, drug delivery, etc. [83,84]. Due to the excellent optical properties of graphene, Sreejith et al. developed a fluorescent hybrid by using graphene oxide (GO) - sheet - coated mesoporous silica nanoparticles. This hybrid possesses remarkable biocompatibility and stability, which serves as a platform for bio-imaging applications, including specific in vitro and in vivo cellular imaging [85]. In addition, while the outstanding mechanical strength, and electrical conductivity are suitable for bone and neural tissue engineering, graphene's large surface area and availability of free $\pi$ electrons make graphene-based materials a good candidate for gene and drug delivery platform $[86,87]$. The D05-H09 (Testing and detection (Except Bacteria, Fungi, Viruses) can be a promising potential in biomedical application, including proteins, ATP, glucose, and so on $[33,89]$. Based on terminal protection of small-molecule-linked DNA by target proteins and the graphene oxide (GO)-assisted DNA assay strategy, He et al. proposed a novel fluorescence method for the testing and detection 
of target proteins [90]. Wang et al. designed an aptamer-carboxyfluoresce in (FAM)/graphene oxide nanosheet (GO-nS) nanocomplex to investigate its ability for molecular probing in living cells [91]. The good selectivity and sensitivity of the aptamer/GO-nS nanocomplex predicted its potential use for intracellular ATP monitoring, testing, and detecting in living cells [91]. This indicates that the research represented by technological fields with high centrality as well as high frequency has a greater impact on the research area of graphene biomedical technology. Consequently, this research represents the comparative competitive advantage and core roles of patent hotspots and fronts in this field.

L03-A02B (nonmetal conductors-carbon and graphite), B14-S18 (drug combination), B05-B02C (Silicon (SI), Selenium (SE), Tellurium (TE), Boron (B) Inorganic, Inert gases), and B05-U03 (Carbon only nanotubes) have relatively high centrality and low frequency, which indicate that they are closely linked with other technological fields and have good development prospects. The first patent front is L03-A02B (nonmetal conductors-carbon and graphite). Graphene, as a non-metal nanomaterial, is carefully considered for use in biomedical applications: material characteristics; interactions with biological components (tissues, cells, and proteins); and biological activity outcomes [33]. In addition, it also regarded as a potential candidate for integrated circuits in biomedical fields. Xiao et al. presented a CMOS-compatible design of graphene-on-silicon hybrid plasmonic-photonic integrated circuits and provided an effective way to excite and implement GSP on a chip [70]. This offered the potential for multichannel and broadband biosensors [70]. San et al. reported the charge transport behavior of protein-shelled inorganic nanoparticles combined with graphene and demonstrated their possible application as flexible and biocompatible bionanoelectronic devices that can be integrated into bioelectric circuits for biomedical purposes [71]. Recently, regarding B14-S18 (drug combination), the development of medicines for complex diseases requires the development of drug combination therapies. Graphene was exploited as a promising carrier of photosensitizers and chemotherapeutics for the drug combination therapy [76]. For example, nano-graphene oxide (nGO) is a carbon allotrope studied for its potential as carrier for chemotherapeutic delivery, and it helps drug combination (doxorubicin and rapamycin) present synergistic anticancer effects in MDA-MB-231, MCF-7, and BT474 cells [77]. Researchers at the University of California San Diego constructed a nanoparticle-based RNAi delivery platform that protects siRNA payloads against nuclease-induced degradation and efficiently delivers them to target cells [78]. The nanocarrier is based on biodegradable mesoporous silicon nanoparticles (pSiNPs), where the voids of the nanoparticles are loaded with siRNA and the nanoparticles are encapsulated with graphene oxide nanosheets (GO-pSiNPs) [78]. As for B05-B02C (Silicon (SI), Selenium (SE), Tellurium (TE), Boron (B) Inorganic, Inert gases), based on selenium doped graphene quantum dots (Se-GQDs), Yang et al. designed a new reversible fluorescent switch for the detection of oxidative hydroxyl radical $(\bullet \mathrm{OH})$ and reductive glutathione $(\mathrm{GSH})$ [79]. This fluorescent switch provided a new detection approach for redox events involved in cellular redox regulation [79]. In addition, Xiao et al. reported the poly (amido amine), functionalized graphene oxide (PAMAM-GO) is an excellent adsorbent in selenium removal from waste water or further application in the biomedical field [80]. Li et al. designed a high-affinity platform by using boron and nitrogen co-doped single-layered graphene quantum dots (BN-SGQDs), which helps nucleic acid detection and imaging in living cells [81]. This platform is suitable for biosensing in complicated biological samples [81]. In the technological field of B05-U03 (Carbon only nanotubes), due to the excellent mechanical and electrical properties, the carbon-based nanomaterials provide benefits such as improved flexibility and stretchability for conformal integration with the soft, curvilinear surfaces of human tissues or organs [88]. The various types of flexible and/or stretchable substrates that are integrated with carbon nanotubes (CNTs) and graphene enable the construction of high-quality active electrode arrays and sensors [88].

Other research hotspots and fronts include, graphene-based natural protein products and polymers (e.g., B04-C03 (Polymers (General)), B04-N04 (Protein/polypeptide of undefined origin (No sequence)), B04-N02 (Animal protein/polypeptide (No sequence)), B04-E01 (Nucleic acid general and other), and B11-C08B (Testing/detection by potentiometry, polarography), A08-S02 
(Solvents, swelling agents), and A12-W11L (Immobilised) Enzymes or microorganisms, microbiology (Polymer use))) [92-97,99,100,103-105], electronic devices for biomedical applications (e.g., S03-E03C1 (Biosensors) and A12-E13 (Instrumentation; measuring; testing-electrical engineering)) [98,102], and nano-materials technology (e.g., A12-W14 (Nanotechnology) and B11-C12 (Nanotechnology (General))) [101,106].

\subsection{Patent Roadmap}

\subsubsection{Country Level Patent Roadmap}

In order to investigate the distribution of patent application in different countries, especially the distribution of high value patents, it is necessary to build a country level patent roadmap and identify the key country holding high value patents in different technological fields. A citation is a document cited by an applicant, third party or a patent office examiner as well as a reference to a previous work. Forward citations are more likely to be a basic patent in specific technological fields and considered as a commonly used indicator of patent value [51]. Therefore, we define patents which have higher number of forward citations as high value patents based on Price's Law [107]. We define Nmax as the maximum value of the number of forward citation and $M$ as the starting point of high value patents that can provide total number of patents. Thus, M-Nmax is high value patents [108]. From 2004 to 2018, the maximum number of forward citations of graphene biomedical technology is $89 . \mathrm{M}=0.749 \times \sqrt{N \max }=0.749 \times \sqrt{89}=7.066$ After rounding, the number of forward citations that greater than or equal to 8 times is regarded as high value patents. By integrating high value patents in different countries with patent hotspots and fronts, the country level patent roadmap can be seen in Figure 4.

The process of patent roadmap is displayed as the following stages. First, we decide the horizontal axis and vertical axis. Specifically, the horizontal axis represents the time-line. We separate the period from 2007 to 2018 into five three-year periods because the patent application among the high value patents begins at the period from 2007 to 2009; and the vertical axis indicates the specific technological field, representing MC (a unique patent classification code indicating the novel technical aspects of the invention, and its commercial applications) which enabled stakeholders to investigate the evolution trend of a target technical area. Second, nodes indicate countries holding high value patents. Third, we employ arrows to link nodes that belong to the same country. Fourth, nodes are marked. We used different colors to display different countries holding high value patents. The red color represents patentees from China, purple from the U.S., green from Korea, blue from the U.K, orange from Germany, pink from France, black from Japan, and yellow from Singapore.

Figure 4 shows the distribution of high value patents in different countries. First, regarding the time stage, patent activities come from the U.S.'s and Germany's assignees in the initial stage (2007-2009) of the technology development; High value patents mainly come from the period of 2010-2012 and 2013-2015. Compared to assignees from European countries, Korea, and Japan, assignees from the U.S. and China have obvious advantages in holding the number of high value patents; although the number of high value patents from 2016 to 2018 is few, it will increase over time. Second, in terms of assignees, Harvard University and University of California from the U.S., Chinese Academy of Sciences and Zhejiang University, and from China, Swansea University from the U.K, University of Freiburg from Germany, Nanosense Inc from France, Kyung Hee University from Korea, and Hitachi, Ltd. From Japan are major assignees holding high value patents in graphene biomedical technology. Third, regarding the technological field, the top three technological field with the largest amount of high value patents are D05-H09 (Testing and detection (Except Bacteria, Fungi, Viruses), B11-C12 (Nanotechnology (General)), and B04-E01 (Nucleic acid general and other), holding 31, 25, and 24 high value patents respectively. The top five technological fields that lacking of high value patent distribution are L03-A02B (nonmetal conductors-carbon and graphite), L03-E03C1 (Biosensors), A08-S02 (Solvents, swelling agents), E05-U05C (Nanofilm), and B05-B02C (Silicon (SI), Selenium (SE), 
Tellurium (TE), Boron (B) Inorganic, Inert gases), which indicates the technology opportunity and the high possibility of potentially high value patent distribution.

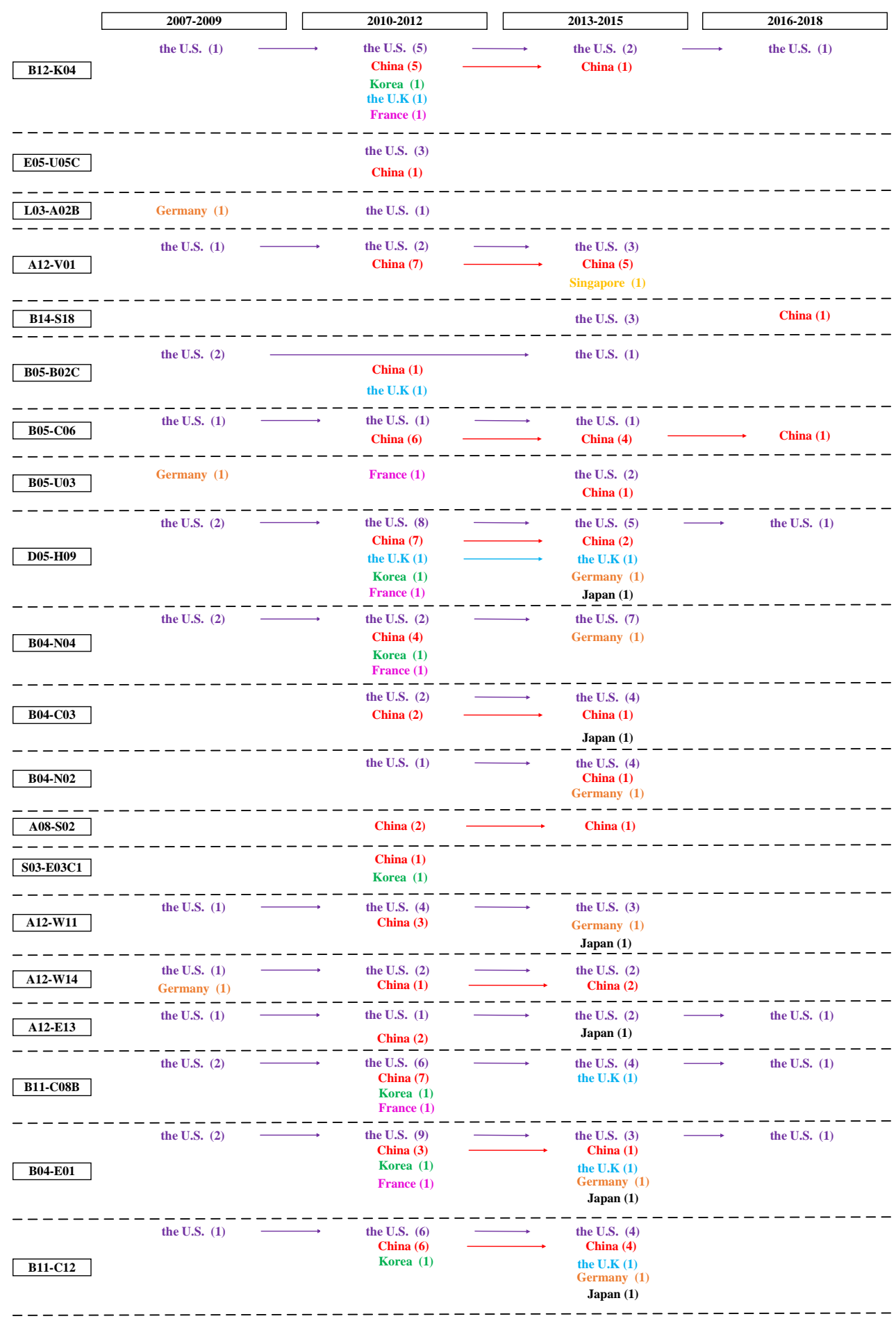

Figure 4. Country level patent roadmap of graphene biomedical technology.

\subsubsection{Assignee Level Patent Roadmap}

In this paper, based on the above patent analysis of TC, we attempt to build an assignee level patent map by integrating competitive position of top assignees with patent hotspots and fronts. This patent roadmap aims to illustrate the patent distribution and evolution trend of the leading assignees and to identify the potential technology opportunity in this field (see Figure 5). 


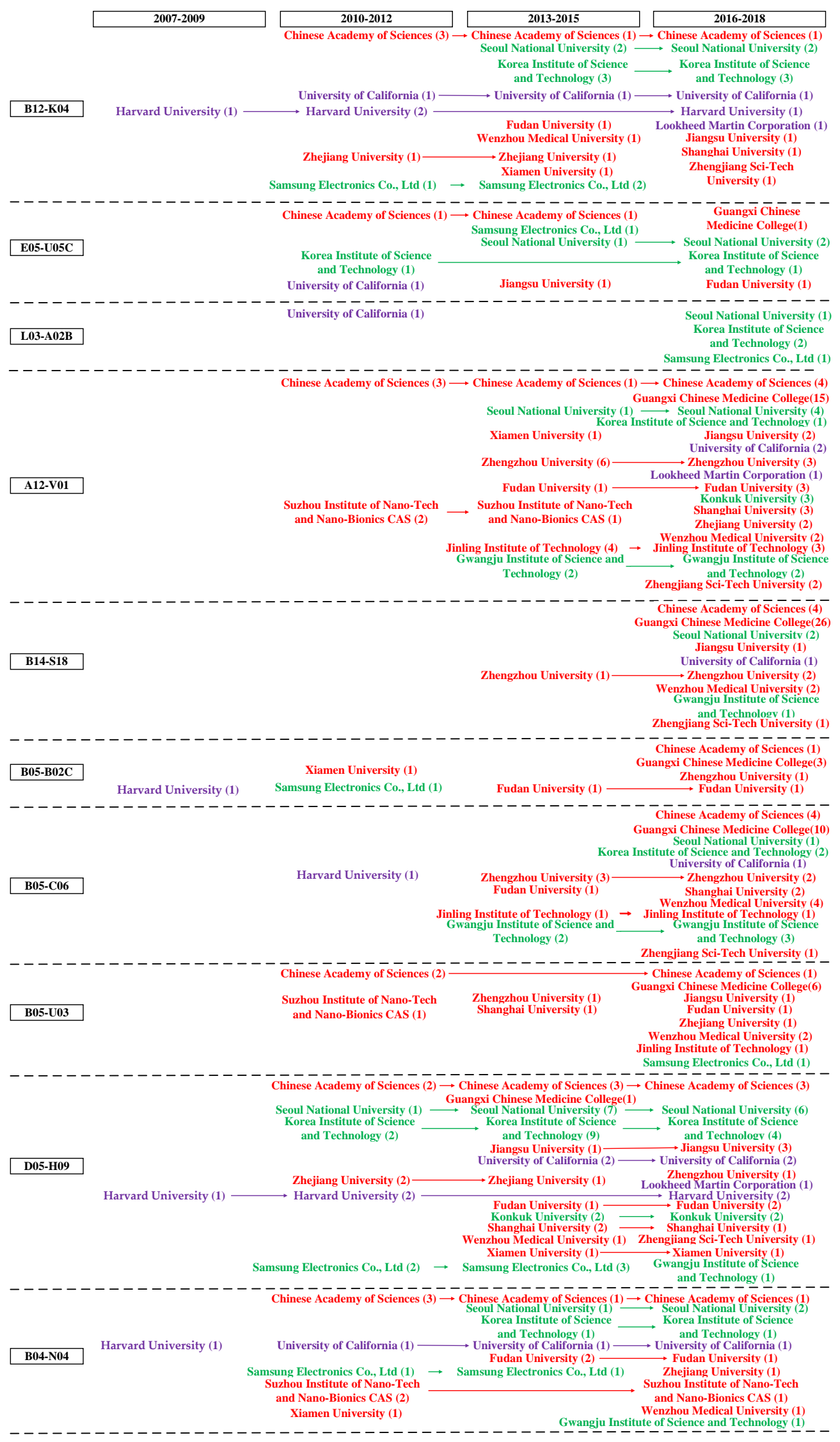

Figure 5. Cont. 


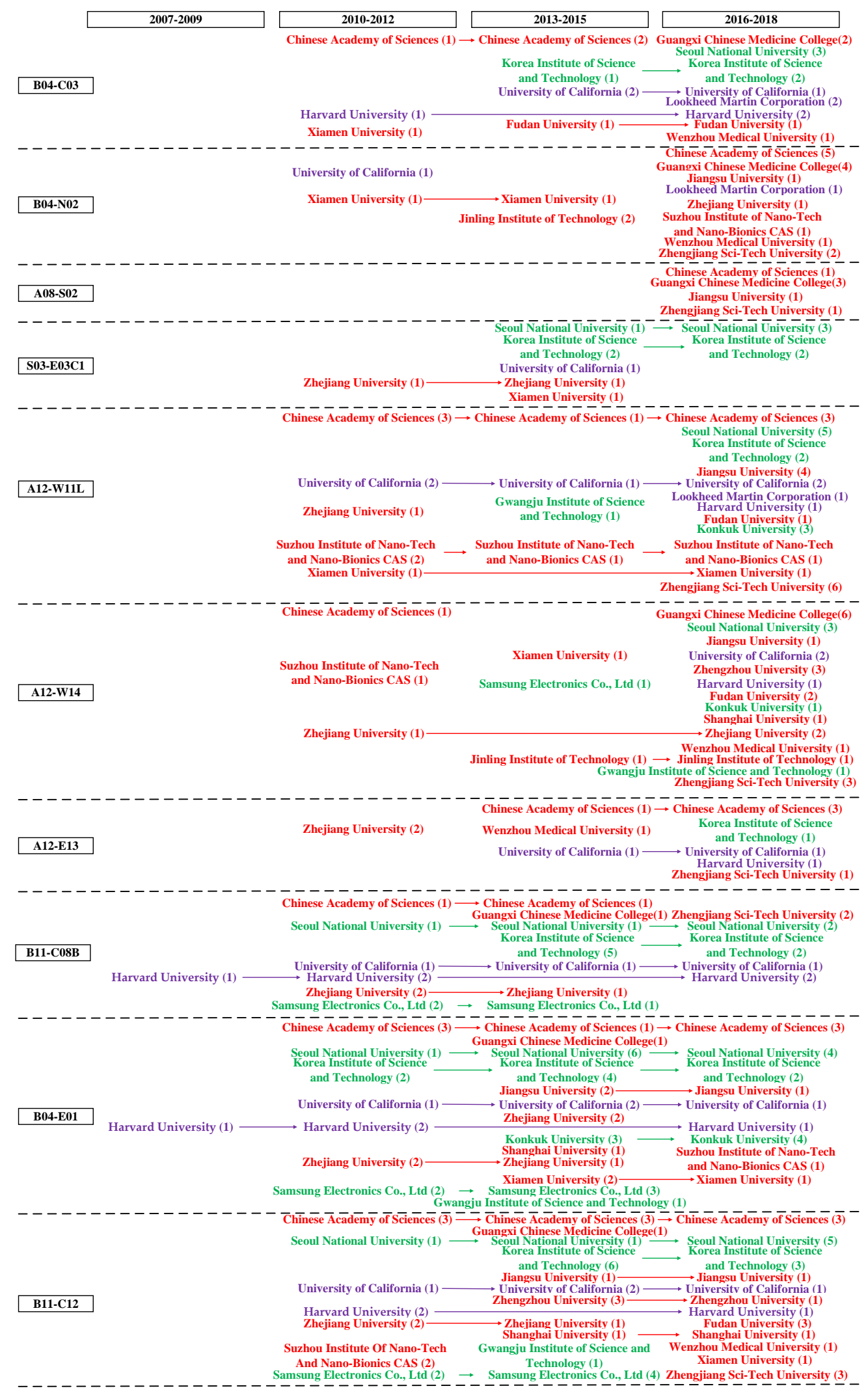

Figure 5. Assignee level patent roadmap of graphene biomedical technology.

The process of patent roadmap mainly includes four stages. First, we decide the horizontal axis and vertical axis. Specifically, the horizontal axis represents the time-line. We separate the period from 2007 to 2018 into five three-year periods, because the patent application among the top 20 assignees 
begins at the period from 2007 to 2009; and the vertical axis indicates the specific technological field, representing by MC (a unique patent classification code indicating the novel technical aspects of the invention, and its commercial applications) which enabled stakeholders to investigate the evolution trend of a target technical area. Second, nodes are determined. Based on the competitive position of top assignees in Figure 3, we selected the top 20 leading patentees with higher competitive advantages in the patent roadmap. Third, we employ arrows to link nodes that belong to the same assignee, displaying the patent distribution of top 20 leading assignees. Fourth, Nodes are marked. We used different colors to show assignees from different countries. The red color represents patentees from China, purple from the U.S., and green from Korea.

As shown in Figure 5, we demonstrate the characteristics of the dynamic development of TC in graphene biomedical technology. Firstly, among the top 20 assignees, their patent applications in patent hotspots and fronts begin at the period from 2007 to 2009. Figure 5 illustrates the following technological fields that entering the graphene biomedical market earlier, such as B12-K04 (Diagnosis and testing), B05-B02C (Silicon (SI), Selenium (SE), Tellurium (TE), Boron (B) Inorganic, Inert gases), D05-H09 (Testing and detection (Except Bacteria, Fungi, Viruses)), B04-N04 (Protein/polypeptide of undefined origin (No sequence)), B11-C08B (Testing/detection by potentiometry, polarography), and B04-E01 (Nucleic acid general and other). Some technological fields can be found the patent application after the year of 2013 (e.g., B14-S18 (Drug combination)) and 2016 (e.g., A08-S02 (Solvents, swelling agents)) with the first data record separately, indicating their preliminary development stage. As for patentees, Harvard University is a powerful leader with first mover advantages in various technological fields, such as B12-K04 (Diagnosis and testing), B05-B02C (Silicon (SI), Selenium (SE), Tellurium (TE), Boron (B) Inorganic, Inert gases), B05-C06 (Elemental C or S), etc. In terms of comprehensive technology distribution, the top three assignees are Chinese Academy of Sciences, University of California, and Seoul National University, with patent filing in 18,16, and 15 patent hotspots and fronts separately. However, although Lockheed Martin Corporation and Konkuk University owned relatively large amounts of patents, they have a lack of technology layout in patent hotspots and fronts.

Secondly, we focus on mining technology opportunities in patent hotspots and fronts. Regarding the five most important patent hotspots and fronts in the graphene biomedical technology, it can be seen that assignees from Korea (e.g., Korea Institute of Science and Technology) and the U.S. (e.g., Harvard University) are powerful leaders in B12-K04 (diagnosis and testing), while except for Chinese Academy of Sciences, most of the Chinese assignees lack patent application in this most important hotspots and fronts in the graphene biomedical technology. As shown in Figure 5, most of the top 20 assignees attach great importance to A12-V01 (Medicines, pharmaceuticals), D05-H09 (Testing and detection (Except Bacteria, Fungi, Viruses), and B05-C06 (Elemental C or S), suggesting their comparative competitive advantages in these important technological fields. We find that E05-U05C (Nanofilm) is a technology opportunity in the patent roadmap. Among the top 20 assignees, only eight of them focus on this field, and the number of patents is very few. The entering time of assignees from China, the U.S., and Korea are very close, and currently Korean assignees hold more patents. Turning our attention to the following four potential research fronts, there are blank spaces in L03-A02B (Nonmetal conductors—carbon and graphite), and B05-B02C (Silicon (SI), Selenium (SE), Tellurium (TE), Boron (B) Inorganic, Inert gases). For example, regarding L03-A02B, only four assignees, three of them from Korea, focus on this field and file a relatively small quantity of patents. It is interesting to find that although Chinese assignees own the largest amount of graphene biomedical patents, none of them have patent application in L03-A02B. The patent layout of the top assignees is relatively comprehensive in B14-S18 (Drug combination), and B05-U03 (Carbon only nanotubes). Chinese assignees entered in earlier and dominated in these two fields, especially Guangxi Chinese Medicine College filing patents actively in the last three years. In terms of other patent hotspots and fronts of graphene biomedical technology, the technology layout of A12-W14 (Nanotechnology), B11-C12 (Nanotechnology (General)), B04-E01 (Nucleic acid general and other), and A12-W11L ((Immobilised) Enzymes or microorganisms, microbiology (Polymer use)) are relatively comprehensive. In addition, we can find patent layout 
opportunities in A08-S02 (Solvents, swelling agents), and S03-E03C1 (Biosensors) severely lacking the technology distribution of the leading assignees, especially those from enterprises.

\section{Conclusions}

This study presents a systematic review that analyzes the TC of graphene related patents in the biomedical field, and this comprehensive framework integrates patent analysis and patent roadmap. Based on patent analysis, we employ annual trend of patent activities, competitive position of top assignees, and patent hotspots and fronts to assess the TC of graphene biomedical technology. In addition, we build two new kind of patent roadmaps from the perspectives of country and assignee separately. Graphene biomedical technology provides a useful case study through which the proposed patent analysis and patent roadmap approaches have been shown to be valid and robust. The initial effort has contributed to the target technology marketplace by identifying TC from patent information, not only enabling stakeholders to understand technological development trend under a dynamic perspective, but also encouraging them to make right decisions in future direction and patent strategic planning.

Some interesting findings are as follows. First, there has been a rapid growth in the global patent application of graphene biomedical technology since 2012. Regarding the number of patents, China, the U.S., and Korea are the top three countries. Compared to the country (e.g., the U.S., Japan, and Korea) entering the market earlier, China, with a steadily growth in the number of patents, becomes a technology catcher and takes the lion's share in global market. Although the U.K, Germany and France play the key roles in patenting activities in European country/region, they still far behind assignees from Asian and the U.S. Second, this research investigated the top assignees with higher competition position in the patenting activity of graphene biomedical technology. Harvard University, Chinese Academy of Sciences, and Lockheed Martin Corporation have relatively higher technological innovation capability in technology strength, while Samsung Electronics Co., Ltd. has an obvious competitive advantage in company resources. Currently no assignee obtains a competitive advantage in both technology strength as well as company resources. In addition, it should be recognized that most of the leading assignees are from universities and research institutes. In terms of high-strength patents, Lockheed Martin Corporation outstrips other assignees, followed successively by Harvard University, Samsung Electronics Co., Ltd., University of California, and Suzhou Institute of Nano-Tech and Nano-Bionics CAS, which illustrate their relatively stronger technological innovation capability in TC. Third, regarding patent hotspots and fronts in graphene biomedical technology, B12-K04 (Diagnosis and testing) is the most important technological field, followed by E05-U05C (Nanofilm), A12-V01 (Medicines, pharmaceuticals), B05-C06 (Elemental C or S), and D05-H09 (Testing and detection (Except Bacteria, Fungi, Viruses)). Lastly, based on country level patent roadmap and assignee level patent roadmap, we identify the potential technology opportunity, which indicating the fewer number of high value patents as well as fewer top assignees with high competition position in the above patent roadmaps. It is clear that E05-U05C (Nanofilm) with higher centrality as well as frequency is the most important patent hotspots and fronts in this field. According to country level patent roadmap, only the U.S. and China hold four high value patents in this field. In the assignee level patent roadmap, only seven assignees with high competition position are distributed their patents in this field. Therefore, E05-U05C (Nanofilm) will be the most important technology opportunity in graphene biomedical technology. One reason for this could be due to gradually mature of large-scale production of graphene film. The other reason is the demand of graphene film in biomedical fields, such as disease diagnosis, bone regeneration, glucose detection, artificial kidneys and dialysis. Other blank spaces include L03-A02B (Nonmetal conductors-carbon and graphite), B05-B02C (Silicon (SI), Selenium (SE), Tellurium (TE), Boron (B) Inorganic, Inert gases), A08-S02 (Solvents, swelling agents), and S03-E03C1 (Biosensors).

The above findings are useful for policy implications on patent distribution of graphene biomedical technology. First, they strengthen industry-university research collaboration and cultivate the 
industrialization ability of patents in universities. Considering that most of the leading assignees are from universities and research institutes, it's necessary to strengthen the construction of a technology transfer and industry-university-research (IUR) platform. Specifically, universities and research institutes should establish technology transfer offices (TTOs), which aim to establish collaborations and working relationships between industry and university and license the inventions of university's faculty and researchers to industry. Second, pay close attention to research hotspots and fronts as well as market demand. The findings indicated that diagnosis and testing, nanofilm, medicines and pharmaceuticals, elemental C or S, and testing and detection (Except bacteria, fungi, viruses) were the hotspots in graphene biomedical fields recently. In addition, stakeholders should focus on market demand, namely biomedical application in the above technological fields (see Table 2). Third, speed up the pace of patent distribution in blank spaces and occupy a dominant position in graphene biomedical technology. It is of great importance for stakeholders to seize technology opportunity and formulate patent strategic planning in the following technological fields: Nanofilm, Nonmetal conductors—carbon and graphite, Silicon (SI), Selenium (SE), Tellurium (TE), Boron (B) Inorganic, Inert gases, Solvents and swelling agents, and Biosensors. Once an assignee has a better patent distribution in technological hotspots and fronts, especially those blank spaces, this assignee will have a higher competitive advantage in technical strength and become dominate in this field.

This study makes an important contribution towards identifying TC and mining technology opportunities by integrating patent analysis and a patent roadmap that has not appeared in existing methodologies of patent review. Compared to previous research, this study makes three important contributions. First, this study provides a new and systematic framework for the dynamic analysis of TC in the given technological field. Our study also extends the research perspectives of TC, namely industry, assignee, and technology, employs patent roadmap to dig out technology opportunity, and then enables stakeholders to understand TC under a dynamic perspective. Second, this study applies a combination of methods to identify TC, namely patent analysis and patent roadmap. Third, it first introduces indicators (e.g., high value patent and competition position of top assignees) to the previous patent roadmap and provides a new methodology for patent roadmap from country level and assignee level. These new patent roadmaps focus on the quality of a patent rather than those studies which only assessed the number of patents. Moreover, the proposed country level patent roadmap and assignee level patent road map can be applied not only to graphene biomedical technology, but to various other areas of emerging technology.

Despite its contribution and several interesting findings, there are still some limitations. First, with the growing attention paid to the development of graphene biomedical technology by both researchers and practitioners, it is obviously that as the number of patents increased rapidly, TC in this field will experience dynamic changes accordingly. In future research, we plan to investigate deeper insights into the dynamic development of TC through patent analysis and patent roadmap. Second, the research methodology in this paper for identifying TC could be further improved. Future studies could pay close attention to the improvement of approaches. Integrating patent data with the PRISMA (preferred reporting items of systematic reviews and meta-analyses) methodology is an interesting future research direction. PRISMA attaches importance to the reporting of reviews evaluating randomized trials as well as reporting systematic reviews of other types of research. In future research, we could adopt the research process of PRISMA, and conduct interviews to obtain valuable data, and integrate patent data with PRISMA methodology. It is suggested that social network analysis (SNA) and data envelopment analysis (DEA) would be effective to achieve the main objective of this study. Specifically, SNA attempts to identify assignees located in the central position in the network, while DEA has been proven to be an efficient approach to evaluating technological innovation efficiency of assignees. Third, the reasons why some technological fields become technology opportunities and others suffer from decline would also be interesting to researchers, practitioners, and policy makers. In future studies, we could carry out a questionnaire survey in leading institutions and interview experts to acquire more practical 
answers as a supplement. The above limitations can be carefully considered as potential research directions in further research.

Author Contributions: Conceptualization, X.Y., X.L. and J.S.; Data curation, X.Y.; Formal analysis, X.Y.; Methodology, X.Y. and X.L.; Software, X.Y.; Supervision, X.L.; Visualization, X.Y.; Writing一original draft, X.Y.; Writing-review \& editing, X.Y., X.L. and J.S.

Funding: This research was funded by the Soft Science Research Program of the Department of Science and Technology of Sichuan Province in China (Grant No. 2018ZR0336), Ministry of Education in China (MOE) Project of Humanities and Social Sciences (Grant No. 18YJC630103), and the Soft Science Research Program of China's State Intellectual Property Office (Grant No. SS18-A-14).

Conflicts of Interest: The authors declare no conflict of interest.

\section{References}

1. Schiavone, F. Strategic reactions to technology competition. Manag. Decis. 2011, 49, 801-809. [CrossRef]

2. Cooper, A.; Smith, C. How Established Firms Respond to Threatening Technologies. Executive 1992, 6, 55. [CrossRef]

3. Adner, R.; Snow, D. Old technology responses to new technology threats: Demand heterogeneity and technology retreats. Ind. Corp. Chang. 2010, 19, 1655-1675. [CrossRef]

4. Utterback, J.; Suárez, F. Innovation, competition, and industry structure. Res. Policy 1993, 22, 1-21. [CrossRef]

5. Subtil Lacerda, J.; van Den Bergh, J. Diversity in solar photovoltaic energy: Implications for innovation and policy. Renew. Sustain. Energy Rev. 2016, 54, 331-340. [CrossRef]

6. Papachristos, G. Diversity in technology competition: The link between platforms and sociotechnical transitions. Renew. Sustain. Energy Rev. 2017, 73, 291-306. [CrossRef]

7. Choi, J.; Hwang, Y. Patent keyword network analysis for improving technology development efficiency. Technol. Soc. Chang. 2014, 83, 170-182. [CrossRef]

8. Karvonen, M.; Kässi, T. Patent citations as a tool for analysing the early stages of convergence. Technol. Soc. Chang. 2013, 80, 1094-1107. [CrossRef]

9. Cantner, U.; Gaffard, J.; Nesta, L. Schumpeterian Perspectives on Innovation, Competition and Growth; Springer Press: Berlin/Heidelberg, Germany, 2009.

10. Blackman, M. Provision of patent information: A national patent office perspective. World Pat. Inf. 1999, 17, 115-123. [CrossRef]

11. Borgstedt, P.; Neyer, B.; Schewe, G. Paving the road to electric vehicles-A patent analysis of the automotive supply industry. J. Clean. Prod. 2017, 167, 75-87. [CrossRef]

12. Chang, S.H. Revealing Development Trends and Key 5G Photonic Technologies Using Patent Analysis. Appl. Sci. 2019, 9, 2525. [CrossRef]

13. Cho, H.; Lim, H.; Lee, D.; Cho, H.; Kang, K. Patent analysis for forecasting promising technology in high-rise building construction. Technol. Forecast. Soc. Chang. 2018, 128, 144-153. [CrossRef]

14. Karvonen, M.; Kapoor, R.; Uusitalo, A.; Ojanen, V. Technology competition in the internal combustion engine waste heat recovery: A patent landscape analysis. J. Clean. Prod. 2016, 112, 3735-3743. [CrossRef]

15. Yang, X.; Yu, X.; Liu, X. Obtaining a Sustainable Competitive Advantage from Patent Information: A Patent Analysis of the Graphene Industry. Sustainability 2018, 10, 4800. [CrossRef]

16. Foo, M.; Gopinath, S. Feasibility of graphene in biomedical applications. Biomed. Pharmacother. 2017, 94, 354-361. [CrossRef] [PubMed]

17. Phaal, R.; Farrukh, C.; Probert, D. Technology roadmapping-A planning framework for evolution and revolution. Technol. Forecast. Soc. Chang. 2004, 71, 5-26. [CrossRef]

18. Li, X.; Zhou, Y.; Xue, L.; Huang, L. Integrating bibliometrics and roadmapping methods: A case of dye-sensitized solar cell technology-based industry in China. Technol. Forecast. Soc. Chang. 2015, 97, 205-222. [CrossRef]

19. Zhang, Y.; Robinson, D.; Porter, A.; Zhu, D.; Zhang, G.; Lu, J. Technology roadmapping for competitive technical intelligence. Technol. Forecast. Soc. Chang. 2016, 110, 175-186. [CrossRef]

20. Liu, X.; Yu, X. Patent analysis for guiding technology transfer from EU/EEA to China: The case of CO2 compressor in CCUS cooperation. In Proceedings of the 2016 Portland International Conference on Management of Engineering \& Technology (PICMET), Honolulu, HI, USA, 4-8 September 2016; pp. 1659-1671. 
21. Qiu, H.H.; Yang, J. An assessment of technological innovation capabilities of carbon capture and storage technology based on patent analysis: A comparative study between china and the United States. Sustainability 2018, 10, 877. [CrossRef]

22. Zhou, Y.; Pan, M.; Urban, F. Comparing the international knowledge flow of China's wind and solar photovoltaic (PV) industries: Patent analysis and implications for sustainable development. Sustainability 2018, 10, 1883. [CrossRef]

23. Goeldner, M.; Herstatt, C.; Tietze, F. The emergence of care robotics-A patent and publication analysis. Technol. Forecast. Soc. Chang. 2015, 92, 115-131. [CrossRef]

24. Madani, F.; Weber, C. The evolution of patent mining: Applying bibliometrics analysis and keyword network analysis. World Pat. Inf. 2016, 46, 32-48. [CrossRef]

25. Reymond, D.; Quoniam, L. A new patent processing suite for academic and research purposes. World Pat. Inf. 2016, 47, 40-50. [CrossRef]

26. de Souza Mendonça, A.K.; Rodrigues Vaz, C.; Lezana, A.G.R.; Anacleto, C.A.; Paladini, E.P. Comparing Patent and Scientific Literature in Airborne Wind Energy. Sustainability 2017, 9, 915. [CrossRef]

27. Choi, S.; Kim, H.; Yoon, J.; Kim, K.; Lee, J. An SAO-based text-mining approach for technology roadmapping using patent information. RD Manag. 2013, 43, 52-74. [CrossRef]

28. Li, X.; Zhou, Y.; Xue, L.; Huang, L. Roadmapping for industrial emergence and innovation gaps to catch-up: A patent-based analysis of OLED industry in China. Int. J. Technol. Manag. 2016, 72, 105-143. [CrossRef]

29. Jeong, Y.; Yoon, B. Development of patent roadmap based on technology roadmap by analyzing patterns of patent development. Technovation 2015, 39-40, 37-52. [CrossRef]

30. Gu, C.; Huang, L. The Study on CNT-FED for Emerging Technology Forecasting by Using Patent Management Map. In Proceedings of the 2009 International Symposium on Information Engineering and Electronic Commerce, Ternopil, Ukraine, 16-17 May 2009; pp. 654-658.

31. Jeong, Y.; Lee, K.; Yoon, B.; Phaal, R. Development of a patent roadmap through the Generative Topographic Mapping and Bass diffusion model. J. Eng. Technol. Manag. 2015, 38, 53-70. [CrossRef]

32. Yu, X.; Zhang, B. Obtaining advantages from technology revolution: A patent roadmap for competition analysis and strategy planning. Technol. Forecast. Soc. Chang. 2017. [CrossRef]

33. Kostarelos, K.; Novoselov, K. Materials science. Exploring the interface of graphene and biology. Science 2014, 344, 261-263. [CrossRef]

34. Jesion, I.; Skibniewski, M.; Skibniewska, E.; Strupiński, W.; Szulc-Dabrowska, L.; Krajewska, A.; Pińkowski, R. Graphene and carbon nanocompounds: Biofunctionalization and applications in tissue engineering. Biotechnol. Biotechnol. Equip. 2015, 29, 1-8. [CrossRef]

35. Wang, J. Electrochemical glucose biosensors. Chem. Rev. 2008, 108, 814-825. [CrossRef] [PubMed]

36. Wang, Z.; Ciacchi, L.C.; Wei, G. Recent Advances in the Synthesis of Graphene-Based Nanomaterials for Controlled Drug Delivery. Appl. Sci. 2017, 7, 1175. [CrossRef]

37. Lee, H.J.; Yook, J.G. Graphene Nanomaterials-Based Radio-Frequency/Microwave Biosensors for Biomaterials Detection. Materials 2019, 12, 952. [CrossRef] [PubMed]

38. Liu, K.; Zhang, J.; Cheng, F.; Zheng, T.; Wang, C.; Zhu, J. Green and facile synthesis of highly biocompatible graphene nanosheets and its application for cellular imaging and drug delivery. J. Mater. Chem. 2011, 21, 12034-12040. [CrossRef]

39. Parlak, O.; Tiwari, A.; Turner, A.; Tiwari, A. Template-directed hierarchical self-assembly of graphene based hybrid structure for electrochemical biosensing. Biosens. Bioelectron. 2013, 49, 53-62. [CrossRef] [PubMed]

40. Viseu, T.; Lopes, C.; Fernandes, E.; Oliveira, M.; Lúcio, M.; Viseu, T. A Systematic Review and Critical Analysis of the Role of Graphene-Based Nanomaterialsin Cancer Theranostics. Pharmaceutics 2018, 10, 282. [CrossRef] [PubMed]

41. Reina, G.; González-Domínguez, J.M.; Criado, A.; Vázquez, E.; Bianco, A.; Prato, M. Promises, facts and challenges for graphene in biomedical applications. Chem. Soc. Rev. 2017, 46, 4400-4416. [CrossRef]

42. Chung, C.; Kim, Y.; Shin, D.; Ryoo, S.; Hong, B.; Min, D.; Chung, C. Biomedical applications of graphene and graphene oxide. Acc. Chem. Res. 2013, 46, 2211-2224. [CrossRef]

43. Ghosal, K.; Sarkar, K. Biomedical Applications of Graphene Nanomaterials and beyond. ACS Biomater. Sci. Eng. 2018, 4, 2653-2703. [CrossRef] 
44. Menaa, F.; Abdelghani, A.; Menaa, B. Graphene nanomaterials as biocompatible and conductive scaffolds for stem cells: Impact for tissue engineering and regenerative medicine. J. Tissue Eng. Regen. Med. 2015, 9, 1321-1338. [CrossRef]

45. Baglieri, D.; Cesaroni, F.; Orsi, L. Does the nano-patent 'Gold rush' lead to entrepreneurial driven growth? Some policy lessons from China and Japan. Technovation 2014, 34, 746-761. [CrossRef]

46. Yang, C.; Zhu, D.; Wang, X.; Zhang, Y.; Zhang, G.; Lu, J. Requirement-oriented core technological components' identification based on SAO analysis. Scientometrics 2017, 112, 1229-1248. [CrossRef]

47. Kwon, S.; Porter, A.; Youtie, J. Navigating the innovation trajectories of technology by combining specialization score analyses for publications and patents: Graphene and nano-enabled drug delivery. Scientometrics 2016, 106, 1057-1071. [CrossRef]

48. Li, M. A novel three-dimension perspective to explore technology evolution. Scientometrics 2015, 105, 1679-1697. [CrossRef]

49. Dhand, V.; Rhee, Y.K.; Kim, J.H.; Jung, D.H. A comprehensive review of graphene nanocomposites: Research status and trends. J. Nanomater. 2013, 2013, 158-171. [CrossRef]

50. UK Intellectual Property Office. An Analysis of Worldwide Patent Filings Relating to Graphene. Available online: https://assets.publishing.service.gov.uk/government/uploads/system/uploads/attachment_data/file/ 312521/informatic-graphene.pdf (accessed on 8 June 2019).

51. Scherer, F.M.; Harhoff, D. Technology policy for a world of skew-distributed outcomes. Res. Policy 2000, 29, 559-566. [CrossRef]

52. Jürgens, B.; Clarke, N.; Jürgens, B. Evolution of CAR T-cell immunotherapy in terms of patenting activity. Nat. Biotechnol. 2019, 37, 370-375. [CrossRef] [PubMed]

53. Islam, N.; Ozcan, S. Nanotechnology innovation system: An empirical analysis of the emerging actors and collaborative networks. IEEE Trans. Eng. Manag. 2013, 60, 687-703. [CrossRef]

54. De Rassenfosse, G. How SMEs exploit their intellectual property assets: Evidence from survey data. Small Bus. Econ. 2012, 39, 437-452. [CrossRef]

55. Innography. Available online: https://www.innography.com/ (accessed on 10 March 2019).

56. Derwent Innovation Index (DII). Available online: https://clarivate.com/products/derwent-innovation/ (accessed on 10 March 2019).

57. The International Union of Pure and Applied Chemistry. Gold Book. Available online: https://goldbook. iupac.org/html/G/G02683.html (accessed on 8 June 2019).

58. Shapira, P.; Youtie, J.; Arora, S. Early patterns of commercial activity in graphene. J. Nanopart. Res. 2012, 14, 811. [CrossRef]

59. Dresselhaus, M.; Araujo, P.; Dresselhaus, M. Perspectives on the 2010 Nobel Prize in physics for graphene. ACS Nano 2010, 4, 6297-6302. [CrossRef] [PubMed]

60. Sharon, M.; Sharon, M. Graphene: An Introduction to the Fundamentals and Industrial Applications; Wiley: Hoboken, NJ, USA, 2015.

61. Hu, G.; Liu, W. Nano/micro-electro mechanical systems: A patent view. J. Nanopart. Res. 2015, 17, 1-10. [CrossRef]

62. Liu, G. Visualization of patents and papers in terahertz technology: A comparative study. Scientometrics 2013, 94, 1037-1056. [CrossRef]

63. Madani, F. Technology Mining bibliometrics analysis: Applying network analysis and cluster analysis. Scientometrics 2015, 105, 323-335. [CrossRef]

64. Keisham, B.; Cole, A.; Nguyen, P.; Mehta, A.; Berry, V. Cancer Cell Hyperactivity and Membrane Dipolarity Monitoring via Raman Mapping of Interfaced Graphene: Toward Non-Invasive Cancer Diagnostics. ACS Appl. Mater. Interfaces 2016, 8, 32717-32722. [CrossRef] [PubMed]

65. Geim, A.; Geim, A. Graphene: Status and prospects. Science 2009, 324, 1530-1534. [CrossRef] [PubMed]

66. Gholizadeh, A.; Voiry, D.; Weisel, C.; Gow, A.; Laumbach, R.; Kipen, H.; Javanmard, M. Toward point-of-care management of chronic respiratory conditions: Electrochemical sensing of nitrite content in exhaled breath condensate using reduced graphene oxide. Microsyst. Nanoeng. 2017, 3, 17022. [CrossRef] [PubMed]

67. Lu, J.; He, Y.; Cheng, C.; Wang, Y.; Qiu, L.; Li, D.; Zou, D. Self-Supporting Graphene Hydrogel Film as an Experimental Platform to Evaluate the Potential of Graphene for Bone Regeneration. Adv. Funct. Mater. 2013, 23, 3494-3502. [CrossRef] 
68. Mansouri, N.; Babadi, A.; Bageri, S.; Hamid, S. Immobilization of glucose oxidase on 3D graphene thin film: Novel glucose bioanalytical sensing platform. Int. J. Hydrogen Energy 2017, 42, 1337-1343. [CrossRef]

69. Mi, B.; Mi, B. Materials science. Graphene oxide membranes for ionic and molecular sieving. Science 2014, 343, 740-742. [CrossRef]

70. Xiao, T.; Cheng, Z.; Goda, K. Graphene-on-silicon hybrid plasmonic-photonic integrated circuits. Nanotechnology 2017, 28, 7. [CrossRef] [PubMed]

71. San, B.; Kim, J.; Kulkarni, A.; Moh, S.; Dugasani, S.; Subramani, V. Combining Protein-Shelled Platinum Nanoparticles with Graphene to Build a Bionanohybrid Capacitor. ACS Nano 2014, 8, 12120-12129. [CrossRef]

72. Ding, X.; Liu, H.; Fan, Y. Graphene-Based Materials in Regenerative Medicine. Adv. Healthc. Mater. 2015, 4, 1451-1468. [CrossRef]

73. Liu, J.; Guo, S.; Han, L.; Wang, T.; Hong, W.; Liu, Y.; Wang, E. Synthesis of phospholipid monolayer membrane functionalized graphene for drug delivery. J. Mater. Chem. 2012, 22, 20634-20640. [CrossRef]

74. Liu, J.; Cui, L.; Losic, D.; Liu, J. Graphene and graphene oxide as new nanocarriers for drug delivery applications. Acta Biomater. 2013, 9, 9243-9257. [CrossRef]

75. Shin, S.; Li, Y.; Jang, H.; Khoshakhlagh, P.; Akbari, M.; Nasajpour, A.; Khademhosseini, A. Graphene-based materials for tissue engineering. Adv. Drug Deliv. Rev. 2016, 105, 255-274. [CrossRef] [PubMed]

76. Zhou, L.; Wei, S.; Ge, X.; Zhou, J.; Jiang, H.; Li, F.; Shen, J. Combination of chemotherapy and photodynamic therapy using graphene oxide as drug delivery system. J. Photochem. Photobiol. B 2014, 135, 7-16. [CrossRef] [PubMed]

77. Thapa, R.; Byeon, J.; Choi, H.; Yong, C.; Kim, J. Pegylated lipid bilayer-wrapped nano-graphene oxides for synergistic co-delivery of doxorubicin and rapamycin to prevent drug resistance in cancers. Nanotechnology 2017, 28, 10. [CrossRef] [PubMed]

78. Kang, J.; Joo, J.; Kwon, E.; Skalak, M.; Hussain, S.; She, Z.; Sailor, M. Self-Sealing Porous Silicon-Calcium Silicate Core-Shell Nanoparticles for Targeted siRNA Delivery to the Injured Brain. Adv. Mater. 2016, 28, 7962-7969. [CrossRef]

79. Yang, S.; Sun, J.; He, P.; Deng, X.; Wang, Z.; Hu, C.; Xie, X. Selenium doped graphene quantum dots as an ultrasensitive redox fluorescent switch. Chem. Mater. 2015, 27, 2004-2011. [CrossRef]

80. Xiao, W.; Yan, B.; Zeng, H.; Liu, Q. Dendrimer functionalized graphene oxide for selenium removal. Carbon 2016, 105, 655-664. [CrossRef]

81. Li, R.; Yuan, B.; Liu, J.; Liu, M.; Gao, P.; Li, Y.; Li, M.; Huang, C. Boron and nitrogen co-doped single-layered graphene quantum dots: A high-affinity platform for visualizing the dynamic invasion of HIV DNA into living cells through fluorescence resonance energy transfer. J. Mater. Chem. B 2017, 5, 8719-8724. [CrossRef]

82. Haddon, R.; Haddon, R. Graphene-the mother of two-dimensional (2-D) materials. Acc. Chem. Res. 2013, 46, 2191-2192. [CrossRef] [PubMed]

83. Novoselov, K.S.; Fal'Ko, V.I.; Colombo, L.; Gellert, P.R.; Schwab, M.G.; Kim, K. A roadmap for graphene. Nature 2012, 490, 192-200. [CrossRef] [PubMed]

84. Cui, X.; Xu, S.; Wang, X.; Chen, C. The nano-bio interaction and biomedical applications of carbon nanomaterials. Carbon 2018, 138, 436-450. Available online: http://search.proquest.com/docview/2122778729/ (accessed on 8 June 2019).

85. Sreejith, S.; Ma, X.; Zhao, Y.; Sreejith, S. Graphene oxide wrapping on squaraine-loaded mesoporous silica nanoparticles for bioimaging. J. Am. Chem. Soc. 2012, 134, 17346-17349. [CrossRef] [PubMed]

86. Shin, S.; Aghaei-Ghareh-Bolagh, B.; Dang, T.; Topkaya, S.; Gao, X.; Yang, S.; Khademhosseini, A. Cell-laden Microengineered and Mechanically Tunable Hybrid Hydrogels of Gelatin and Graphene Oxide. Adv. Mater. 2013, 25, 6385-6391. [CrossRef]

87. Jung, H.; Lee, M.; Kong, W.; Do, I.; Hahn, S. Nano graphene oxidehyaluronic acid conjugate for target specific cancer drug delivery. RSC Adv. 2014, 4, 14197-14200. [CrossRef]

88. Kim, T.; Cho, M.; Yu, K.; Kim, T. Flexible and Stretchable Bio-Integrated Electronics Based on Carbon Nanotube and Graphene. Materials 2018, 11, 1163. [CrossRef]

89. Wang, X.; Zhang, X. Electrochemical co-reduction synthesis of graphene/nano-gold composites and its application to electrochemical glucose biosensor. Electrochim. Acta 2013, 112, 774-782. [CrossRef]

90. He, Y.; Xing, X.; Tang, H.; Pang, D. Graphene Oxide-Based Fluorescent Biosensor for Protein Detection via Terminal Protection of Small-Molecule-Linked DNA. Small 2013, 9, 2097-2101. [CrossRef] 
91. Wang, Y.; Li, Z.; Hu, D.; Lin, C.; Li, J.; Lin, Y. Aptamer/Graphene Oxide Nanocomplex for in Situ Molecular Probing in Living Cells. J. Am. Chem. Soc. 2010, 132, 9274-9276. [CrossRef] [PubMed]

92. Mao, S.; Lu, G.; Yu, K.; Bo, Z.; Chen, J. Specific Protein Detection Using Thermally Reduced Graphene Oxide Sheet Decorated with Gold Nanoparticle-Antibody Conjugates. Adv. Mater. 2010, 22, 3521-3526. [CrossRef] [PubMed]

93. Shen, H.; Liu, M.; He, H.; Zhang, L.; Huang, J.; Chong, Y. PEGylated graphene oxide-mediated protein delivery for cell function regulation. ACS Appl. Mater. Interfaces 2012, 4, 6317-6323. [CrossRef] [PubMed]

94. Luo, X.; Weaver, C.; Tan, S.; Cui, X. Pure graphene oxide doped conducting polymer nanocomposite for bio-interfacing. J. Mater. Chem. B 2013, 1, 1340-1348. [CrossRef] [PubMed]

95. Wang, K.; Ruan, J.; Song, H.; Zhang, J.; Wo, Y.; Guo, S.; Cui, D. Biocompatibility of Graphene Oxide. NanoscIale Res. Lett. 2010, 6, 8. [CrossRef] [PubMed]

96. Park, S.; An, J.; Jung, I.; Piner, R.; An, S.; Li, X. Colloidal suspensions of highly reduced graphene oxide in a wide variety of organic solvents. Nano Lett. 2009, 9, 1593-1597. [CrossRef] [PubMed]

97. Zhou, M.; Dong, S. Bioelectrochemical interface engineering: Toward the fabrication of electrochemical biosensors, biofuel cells, and self-powered logic biosensors. Acc. Chem. Res. 2011, 11, 1232-1243. [CrossRef] [PubMed]

98. Peña-Bahamonde, J.; Nguyen, H.; Fanourakis, S.; Rodrigues, D. Recent advances in graphene-based biosensor technology with applications in life sciences. J. Nanobiotechnol. 2018, 16, 75. [CrossRef]

99. Zeng, Q.; Cheng, J.; Tang, L.; Liu, X.; Liu, Y.; Li, J.; Jiang, J. Self-Assembled Graphene-Enzyme Hierarchical Nanostructures for Electrochemical Biosensing. Adv. Funct. Mater. 2010, 20, 3366-3372. [CrossRef]

100. Jin, L.; Yang, K.; Yao, K.; Zhang, S.; Tao, H.; Lee, S. Functionalized graphene oxide in enzyme engineering: A selective modulator for enzyme activity and thermostability. ACS Nano 2012, 6, 4864-4875. [CrossRef]

101. Fan, H.; Wang, L.; Zhao, K.; Li, N.; Shi, Z.; Ge, Z. Fabrication, mechanical properties, and biocompatibility of graphene-reinforced chitosan composites. Biomacromolecules 2010, 11, 2345-2351. [CrossRef] [PubMed]

102. Song, B.; Cuniberti, G.; Sanvito, S.; Fang, H. Nucleobase adsorbed at graphene devices: Enhance bio-sensorics. Appl. Phys. Lett. 2012, 100, 063101. [CrossRef]

103. Terse-Thakoor, T.; Badhulika, S.; Mulchandani, A. Graphene based biosensors for healthcare. J. Mater. Res. 2017, 32, 2905-2929. [CrossRef]

104. Cui, L.; Song, Y.; Ke, G.; Guan, Z.; Zhang, H.; Lin, Y.; Yang, C. Graphene Oxide Protected Nucleic Acid Probes for Bioanalysis and Biomedicine. Chem. A Eur. J. 2013, 19, 10442-10451. [CrossRef] [PubMed]

105. Bonanni, A.; Ambrosi, A.; Pumera, M. Nucleic Acid Functionalized Graphene for Biosensing. Chem. A Eur. J. 2012, 18, 1668-1673. [CrossRef] [PubMed]

106. Wu, P.; Qian, Y.; Du, P.; Zhang, H.; Cai, C. Facile synthesis of nitrogen-doped graphene for measuring the releasing process of hydrogen peroxide from living cells. J. Mater. Chem. 2012, 22, 6402-6412. [CrossRef]

107. Liu, Y.; Liu, L.; Yan, Z. Characteristic analysis of the CNT technical innovation based on patentometrics. Sci. Res. Manag. 2016, 4, 337-345. Available online: http://www.en.cnki.com.cn/Article_en/CJFDTOTALKYGL2016S1049.htm (accessed on 8 June 2019).

108. Yang, X.; Yu, X. Patent Analysis for Graphene Technology in ICT Industry. In Proceedings of the International Association for Management of Technology (IAMOT) 2017 Conference, Vienna, Austria, 14-18 May 2017; pp. 1125-1141.

(C) 2019 by the authors. Licensee MDPI, Basel, Switzerland. This article is an open access article distributed under the terms and conditions of the Creative Commons Attribution (CC BY) license (http://creativecommons.org/licenses/by/4.0/). 